Please do not destroy or throw away this publication. If you have no further use for it, write to the Geological Survey at Washington and ask for a frank to return it

UNITED STATES DEPARTMENT OF THE INTERIOR

Ray Lyman Wilbur, Secretary

GEOLOGICAL SURVEY

W. C. Mendenhall, Director

Professional Paper 175-C

\title{
REPLACEMENT ORIGIN OF THE ALBITE GRANITE NEAR SPARTA, OREGON
}

BY

JAMES GILLULY

Shorter contributions to general geology, 1932-33

(Pages 65-81)

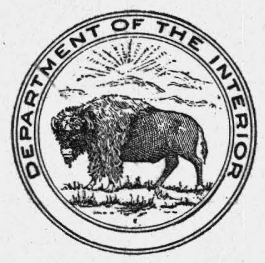

UNITED STATES

GOVERNMENT PRINTING OFFICE

WASHINGTON : 1933 


\section{CONTENTS}

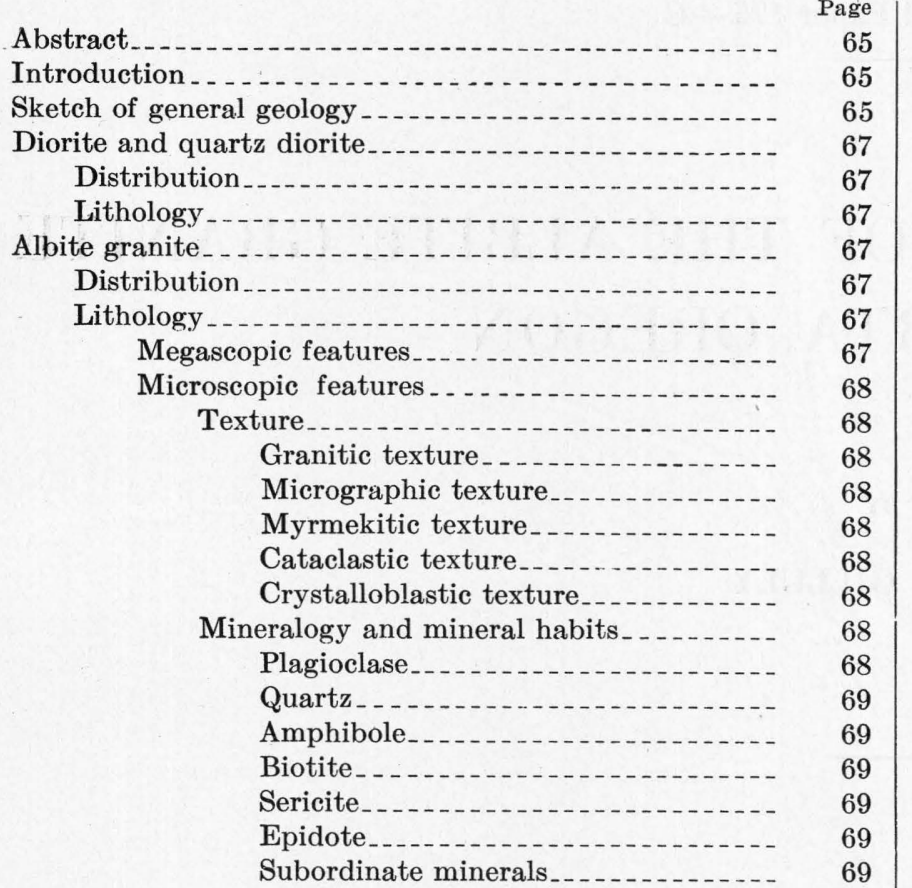

Zone gradational between quartz diorite and albite

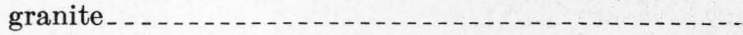

Field relations

Lithology

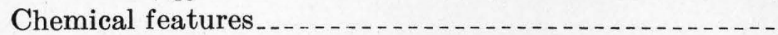

Conclusions respecting relationship..................

Evidence of late magmatic or hydrothermal mineral formation . - . - .

Textural evidence...

Mineralogic evidence.............................

Summary of microscopic evidence............

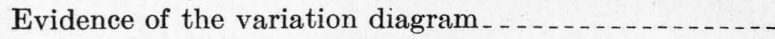

Source of the albitizing solutions

Solutions derived from the solid diorite by metamorphism

Solutions derived from the intruded greenstones..-

Local rest-magma solutions. ...................

Hydrothermal solutions of deep-seated origin ...... Selective enrichment of soda in hydrothermal solutions_ Albitization in other granitic rocks _... Other albite granites...............

Field associations

Mineralogic and textural features.............. Conclusion _....... Acknowledgments . . . .

Page

\section{ILLUSTRATIONS}

Plate 19. $A$, Albite crystal embayed by quartz in structure interpreted as due to replacement; $B$, Micrographic texture of albite granite; $C$, "Brain-coral" myrmekite in albite granite; $D$, Cataclastic albite granite

20. $A$, Cataclastic albite granite; $B$, Crystalloblastic albite granite; $C, D$, Albite granite

21. A, Albite surrounded by micrographic rosette of albite and quartz; $B$, Enlarged photograph of border of micrographic intergrowth against the central albite crystal; $C$, Enlarged outer fringe of micrographic intergrowth shown in $A ; D$, Graphic intergrowth of albite and quartz showing some resemblance to myrmekite

22. A, Albite, showing tendency toward chessboard structure; $B$, Albite granite cut by veinlets of clear albite; $C$, Wisps of residual. albite in quartz which is replacing it; $D$, Albite crystal partly replaced by quartz in pseudographic structure.
Plate 23. $A$, Albite being replaced by quartz; $B$, Sericitic albite coated and veined by clear albite; $C$, Albite partly replaced by quartz in crude graphic structure; $D$, Central core of somewhat saussuritic andesine surrounded by albite in relation interpreted to signify replacement.

FigURe 1. Sketch map showing general geology of parts of the Baker and Pine quadrangles and distribution of intrusive rocks

2. Variation diagram showing chemical composition of quartz diorite and albite granite, contrasted with the weighted variation diagram of the Katmai rocks and a variation diagram constructed from the analyses of the opdalite-trondhjemite series. 


\title{
REPLACEMENT ORIGIN OF THE ALBITE GRANITE NEAR SPARTA, OREGON
}

\author{
By James Gilluly
}

\begin{abstract}
The albite granite near Sparta, in the foothills of the Wallowa Mountains of eastern Oregon, is thought to be a product of albitization and partial silicification of an earlier quartz diorite. These changes are attributed to late magmatic and postmagmatic replacement of the almost completely solidified quartz diorite by solutions derived probably through filter pressing from lower portions of the same mass. These solutions were guided, at least in part and probably entirely, by brecciated zones in the quartz diorite.

Mineralogic changes effected were the replacement of the andesine and subordinate orthoclase of the quartz diorite by albite, the replacement of some of the common green hornblende by the soda amphibole, hastingsite, and the introduction of large quantities of dark-blue quartz. This quartz is decidedly different in habit from that of normal granites in that it occurs in irregular nests and veinlets penetrating the rock in many directions. Most of the dark minerals have been removed. Myrmekite and micrographic textures are common in the albite granite, though absent from the unaffected quartz diorite.

That the albitization and other changes of the albite granite have resulted from later reactions on the quartz diorite is shown by field relations, microscopic study, and chemical analyses. The process is considered analogous to that of large-scale pegmatitization.

The rocks are all of presumable Mesozoic age.

Many albite granites elsewhere are characterized by features like those found in the Sparta rocks. These include common association with crushing phenomena, widespread occurrence of graphic textures, of epidote and other low-temperature and hydrous mafic minerals, and of milky and rutilated quartz, and unusual amounts of replacement. Although the findings of the writer with respect to the Sparta rocks are in agreement with the thesis of Bowen that albite granites are of hydrothermal origin, it does not appear that a survey of the world literature on such rocks is at all conclusive on the matter.
\end{abstract}

\section{INTRODUCTION}

In connection with a study of the mineral deposits of eastern Oregon ${ }^{1}$ the geology of the Baker quadrangle and portions of the Pine quadrangle was mapped by the writer and his assistants during 1929 and 1930 . In the course of this work opportunity was afforded to study in some detail the soda granite near Sparta, briefly described by Lindgren, ${ }^{2}$ together with the diorite and quartz diorite closely associated with it and the gabbroic rocks associated with similar albite granites elsewhere in the general region. Owing to the unusual composition of the rocks and their intimate association with the diorites and gabbros some time was spent in

\footnotetext{
1 Gilluly, James, Copper deposits near Keating, Oreg.: U. S. Geol. Survey Bull 830 , pp. 1-32, 1932 . Gilluly, James, Reed, J. C., and Park, C. F., jr., Some mining districts of eastern Oregon (in preparation).

${ }^{2}$ Lindgren, Waldemar, The gold belt of the Blue Mountains of Oregon: U. S. Geol. Survey Twenty-second Ann. Rept., pt. 2, pp. 585-586, 732, 734, 1901.
}

studying their field relations. During this work and subsequent office studies the writer was led to the following hypothesis to explain the origin of these interesting rocks:

The albite granite is the product of albitization and partial silicification of portions of the gabbro, diorite, and quartz diorite. These changes are the result of the late magmatic and postmagmatic replacement of almost or quite completely solidified diorite. The replacement was brought about by circulating solutions or extremely hydrous rest-magmas derived from deeper levels in the mass, in part at least by "filter pressing" and in large part guided by brecciated zones in the diorite.

\section{SKETCH OF GENERAL GEOLOGY}

The dominant geologic units of the northern part of the Baker quadrangle and the northwestern part of the Pine quadrangle are (1) a series of altered lavas and pyroclastic rocks, with subordinate limestones, of Permian age; (2) a group of plutonic masses including gabbro, diorite, quartz diorite, and albite granite, of post-Permian, pre-Tertiary age, intruding these old volcanic rocks; (3) a series of Tertiary lava flows and associated fluviatile and lacustrine sediments unconformably overlying the earlier rocks; (4) the Quaternary alluvium of Baker Valley and terrace gravel along the larger streams.

The Permian volcanic rocks are characterized throughout by the dominance of albite, although residual andesine and labradorite are not unknown. They are highly altered and sheared, and the dark minerals have been largely altered to chlorite and epidote. The rocks recognized include keratophyre, quartz keratophyre, spilite, albite diabase, metaandesite, and metabasalt. They constitute a spilitic association in the sense of Dewey and Flett. ${ }^{3}$ Pillow. structure, a common but not invariable feature of spilitic lavas, was not recognized, although if originally present it may have been destroyed by later shearing.

The formation is very thick, probably not less than 4,000 feet. It has been strongly, possibly isoclinally folded and strikes west-northwest in consonance with the regional trend of the pre-Tertiary formations of the Blue Mountains.

Gabbro, diorite, quartz diorite, and albite granite intrude these Permian volcanic rocks. The diorites

3 Dewey, Henry, and Flett, J. S., British pillow lavas and the rocks associated with them: Geol. Mag., dec. 5, vol. 8, pp. 202-209, 241-248. 1911. 
and gabbros are found widely in both the Baker and Pine quadrangles; the larger bodies of albite granite, however, though closely associated with these diorites

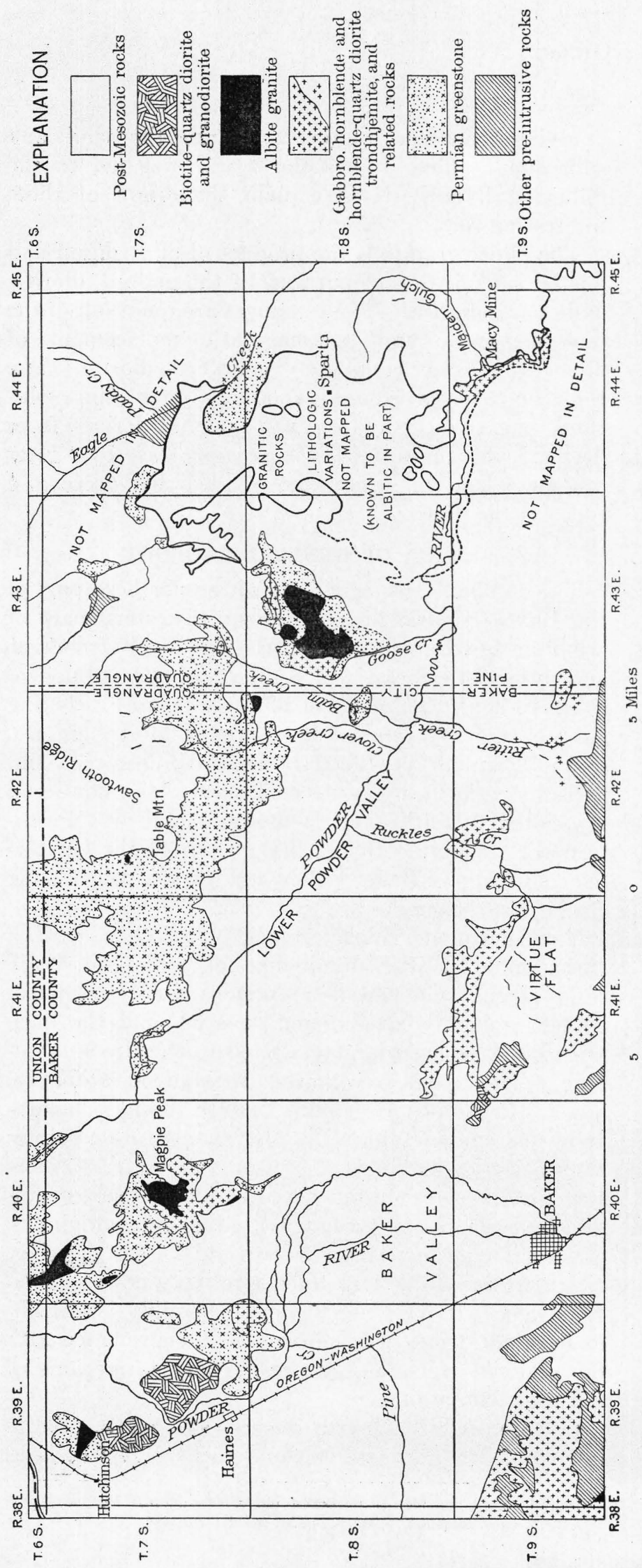

and gabbros within the belt where they occur, seem to be limited to a belt extending from a point near Hutchinson, in the Baker quadrangle, to the mouth of Maiden Gulch, in the Pine quadrangle. It is perhaps significant that this belt of albitic granites corresponds with the belt of Permian volcanic rocks, although the fact that a few smaller bodies of albite granite are found farther south, in the midst of large gabbro masses in Carboniferous argillite, seems to invalidate any suggestion of genetic relationship. The unconformably overlapping Tertiary and Quaternary formations cover much of the surrounding country, so that the actual extent of the albite granites may be considerably greater than is exposed. These relations are all brought out on Figure 1.

The age of the intrusive rocks is not known with certainty beyond the fact that they are postPermian and pre-Miocene. Lindgren, ${ }^{4}$ on the basis of regional reconnaissance, tentatively referred them to a post-Jurassic, pre-Chico Cretaceous age. Differences in degree of metamorphism between the Permian and Triassic rocks of the general region and the occurrence of fragments of a quartz diorite in Triassic breccia. on Eagle Creek 5 suggest, however, that they may be in part of pre-Triassic age, as was suggested by Lindgren ${ }^{6}$ for the gabbros and diorites. of the Virtue district. Possibly the common association in other regions of albite granites and spilites pointed out by Dewey and Flett 7 may be considered as strengthening the probabilities of a pre-Triassic age, as it may imply a consanguinity between the Permian volcanic series and the later albite granite; however, this correlation is not supported by observations made in this area, except by the suggestive geographic association of the spilites and albite granite, and if the proposed hypothesis is sound the origin of the albite granite has no connection with the extrusion of the greenstones, although it has a possible connection with their albitization. Indeed, it is possible that both pre-Triassic and post-Triassic gabbros and diorites occur in the Blue Mountains, perhaps within the area here considered.

The plutonic rocks of the region can be divided into at least two groups on the basis of the metamorphism they have undergone. The older group, whose rocks in nearly every outcrop show signs of crushing and intense deformation, embraces a wide variety of rocks ranging from pyroxenite and gabbro through hornblende diorite, quartz diorite, and soda-rich quartz diorite.

\footnotetext{
4 Lindgren, Waldemar, op, cit., p. 596.

${ }^{5}$ Idem, p. 734.

6 Idem, p. 596.

7 Dewey, Henry, and Flett, J. S., op. cit., p. 209.
} 
(trondhjemite) to albite granite. The younger group consists of biotite-quartz diorite, subordinate granodiorite, and a few related dikes and is essentially undeformed in all its facies. This younger group, so far as now known, is not associated with any occurrence of albite granite and will not be further discussed.

Although albite granite occurs in gabbro in the southern part of the Baker quadrangle (not shown in fig. 1) it is associated with hornblende-quartz diorite where studied in detail, near Magpie Peak, on Goose Creek, and in Maiden Gulch.

\section{DIORITE AND QUARTZ DIORITE}

\section{DISTRIBUTION}

Intrusive masses of the older group of gabbro, diorite, and quartz diorite are abundant in the Blue Mountains, from Prairie City to the Snake River, a distance of about 80 miles. Considerable masses occur around Magpie Peak, near Virtue Flat, and along Goose Creek and Maiden Gulch; smaller bodies occur on Balm Creek, near Clover Creek, and near Haines.

In places the dioritic rocks grade marginally into hornblendite and gabbro, elsewhere by increase of quartz to quartz diorite, or locally even to trondhjemite. These changes are due to local variations in the quantitative relations of the common minerals and undoubtedly arose during the magmatic stage in the formation of the rocks. Transition to albite granite is of a different category, involving, it appears, processes that are not strictly magmatic in character. (See pp. 71-76.)

\section{LITHOLOGY}

In hand specimens the common diorite is a mediumgray equigranular rock, with average grain about 2 to 4 millimeters in diameter. Plagioclase and hornblende are conspicuous. Quartz is visible in some specimens but absent from others.

Under the microscope the rock shows a typical granitic texture. Euhedral and subhedral plagioclase and hornblende occur, separated by interstitial quartz. Orthoclase is present very sparingly, making up hardly 3 per cent of the rock. A few grains of augite, now largely altered to actinolite, occur, with accessory titanite, apatite, magnetite, and ilmenite.

The plagioclase (andesine) is zoned normally, with cores of composition near $A b_{50} A_{50}$ and border zones about $A b_{60} A n_{40}$. In most thin sections it is slightly saussuritized, with minute epidote grains and locally a little sericite, set in an albitic base, but many quite unaltered grains occur. Ordinarily as in most other examples of saussuritic alteration, there has been but little migration of material, the bulk composition of the original feldspar being essentially duplicated by that of the mineral aggregate replacing it.

Orthoclase is a minor constituent occurring interstitially to all the other minerals. Quartz is present in varying amounts, commonly only a few per cent, and shows normal granitic relations, as it is interstitial to the plagioclase and mafic minerals.

Most of the amphibole is common green hornblende. It is pleochroic in yellowish green and greenish brown, $\mathrm{X}<\mathrm{Y}=\mathrm{Z}$. It is optically negative, with moderate $2 \mathrm{~V}$, an extinction angle of $22^{\circ} \mathrm{Z} \wedge \mathrm{c}$, birefringence about 0.021 . Some alteration to chlorite has occurred in a few specimens.

Small amounts of epidote in addition to that in the saussurite also occur in veinlets penetrating the rock.

Aside from their marked association with the mafic minerals, nothing noteworthy was observed respecting the accessory minerals.

\section{ALBITE GRANITE} DISTRIBUTION

The largest mass of albite granite in the area is that near Sparta, where it was first recorded by Lindgren. ${ }^{8}$ A detailed survey of this mass has not been carried out, and the outlines given in Figure 1 are taken from an unpublished reconnaissance map by. C. P. Ross. It is known to contain considerable areas of nonalbitic rock, although the most conspicuous exposures consist of albite granite, doubtless because of the high quartz content and consequent resistance to erosion of this rock. Another large body crops out in the canyon of Goose Creek. Smaller bodies occur (1) near the mouth of Maiden Gulch, (2) just east of Clover Creek in sec. 1, T. 8 S., R. 42 E., (3) around Magpie Peak, (4) near the corner of Ts. 6 and 7 S., Rs. 39 and 40 E., and (5) northeast of Hutchinson.

All the larger bodies are very closely associated with masses of diorite or quartz diorite. Detailed examination of the favorably exposed masses, particularly that along Goose Creek and that at the mouth of Maiden Gulch, reveals gradational phenomena. These, with the transitional varieties of rock, can be more appropriately discussed after representative specimens of the albite granite have been described.

\section{LITHOLOGY}

MEGASCOPIC FEATURES

Over considerable areas the albite granite is sheared and even mylonitized. The more intensely sheared parts are reduced to streaked rocks, with epidote and quartz veinlets penetrating a chalky-appearing but firm, flinty groundmass in which feldspar but no dark minerals can be seen. Elsewhere the rock shows less conspicuous shearing, although it seems everywhere to be somewhat more brecciated than the adjoining diorite or quartz diorite.

There is a marked inverse correlation between the amount of shearing that a specimen of this granite has undergone and the amount of mafic material it contains. The more sheared the rock the less recognizable amphibole it retains and the more greenish are the feldspars from included epidote.

\footnotetext{
${ }_{8}$ Lindgren, Waldemar, op. cit., p. 734.
} 
The less crushed albite granite is a medium-gray, almost equigranular rock in which plagioclase, amphibole, and quartz of a notably blue hue are recognizable. The grain size averages about 2 to 4 millimeters. In the more sheared portions the dark minerals are less plentiful and the quartz more prominent. Some of these rocks show a remarkable pseudoporphyritic texture, with large irregular aggregates of bluish quartz as much as 2 centimeters in diameter set in a groundmass of greenish plagioclase and subordinate epidote. In some specimens there are small veinlike masses of bluish quartz 3 or 4 centimeters long and 2 to 5 millimeters wide.

\section{MICROSCOPIC FEATURES}

\section{TEXTURE}

In thin section the albite granite is extremely variable in both texture and mineralogy. Textural varieties include granitic, micrographic, myrmekitic, cataclastic, and crystalloblastic, but gradations between nearly all these varieties are to be found.

Granitic texture.-Some slides superficially resemble those of the quartz diorite in a striking manner. The feldspar grains are of about the same size, from 2 to 4 millimeters in diameter; the hornblende does not noticeably differ from that of the quartz diorite. Quartz is, however, noticeably more plentiful, and its habit is considerably different from that of the quartz diorite in that it is not confined to wedge-shaped interstices between the feldspar grains but occurs also in irregularly lobate and vermiform masses partly embedded in the plagioclase. (See pls. 19, $A ; 22, C$, $D ; 23, A$.)

Micrographic texture.-Locally the albite granite has a handsome micrographic texture (pl. 19, B) and elsewhere a less regular graphic texture (pl. $23, C)$. The grain size is, of course, much less uniform than in the varieties with normal granitic texture. Rosettes of graphically intergrown albite and quartz attain diameters of 3 millimeters or even more. These specimens are characteristically less mafic than the granitic varieties.

Myrmekitic texture.-The albite granites are notably more myrmekitic than the quartz diorite. Typical "brain-coral" myrmekite is common (see pl. 19, C) but always in small amounts. There seems to be a gradation between myrmekitic and graphic texture, and the association is so close and so striking as to impel the belief that they are of common origin. Much myrmekitic intergrowth is found where no potash feldspar is to be seen. Myrmekite is also present, though not abundant, in the cataclastic albite granite.

Cataclastic texture.-Many of the more siliceous albite granites are notably cataclastic, all gradations from mere mortar structure to complete mylonitic schistosity being seen. (See pls. 19, D; 20, A.) There is a marked direct correlation between the presence of brecciation and high quartz content.
Crystalloblastic texture.-A very few specimens of albite granite have typical crystalloblastic textures. These are very poor in dark minerals. (See pl. 20, B.)

MINERALOGY AND MINERAL HABITS

The minerals of the albite granite include plagioclase, quartz, amphibole, biotite, titanite, "iron ores," zircon, apatite, rutile (?), epidote, clinozoisite, sericite, and chlorite.

Plagioclase.-The plagioclase commonly resembles superficially that of the diorite, both in dimensions and in inclusion-marked zones. It is, however, not andesine but albite, glassy and clear around the borders of the grains in zones commonly about one-fifth of the thickness of the grains. The inner parts of many of the plagioclase crystals are obscured by masses of highly refracting grains of epidote, clinozoisite, and sericite. These masses so thoroughly mask the feldspar base in which they are embedded that its composition is not certain, although it seems to be albite of the same index as that in the clear zone about it. (See pls. 20, $C, D ; 23, B$.) This variety of albite is closely analogous to the products of normal saussuritization. However, there is considerable evidence, outlined later, that its formation was part of a more fundamental change.

A few specimens contain water-clear albite with no saussuritic products. This clear variety is commonly found in the rock having crystalloblastic texture and less commonly in the other rocks.

In a very few specimens two varieties of plagioclase are found- $a$ central core of andesine surrounded by a wide rim of partly clear, partly cloudy albite. Tongues and vermicular and scalloped masses of albite anastomose through the central core of andesine in a very complex manner. The significance of this relation is referred to below. Certainly the irregular boundaries between the albite and andesine are not normal zoning. (See pl. 23, D.)

In the graphic varieties the albite is cloudy but contains no recognizable epidote or sericite inclusions and forms rosettes radiating from a central crystal, which commonly has both polysynthetic and carlsbad twinning. The central crystal, as well as the radiating rosettes, commonly includes blebs, and dotlike and hooklike masses of quartz, all of which show uniform optical orientation over considerable segments of a single rosette, though two to five or more such quartz crystals are required to compose the entire rosette. (See pl. 21, $A, B, C, D$.)

Myrmekitic albite possesses the usual features of the texture. (See pls. $19, C ; 21, D$.)

A good many specimens show the variety known as chessboard albite. (See pl. 22, A.) This is characterized by polysynthetic twinning which does not pass entirely across the crystal but is interrupted at cross lines by oppositely oriented twins, resulting in a steplike extinction reminiscent of a chessboard. (See p.73.) 
U. S. GEOLOGICAL SURVEY

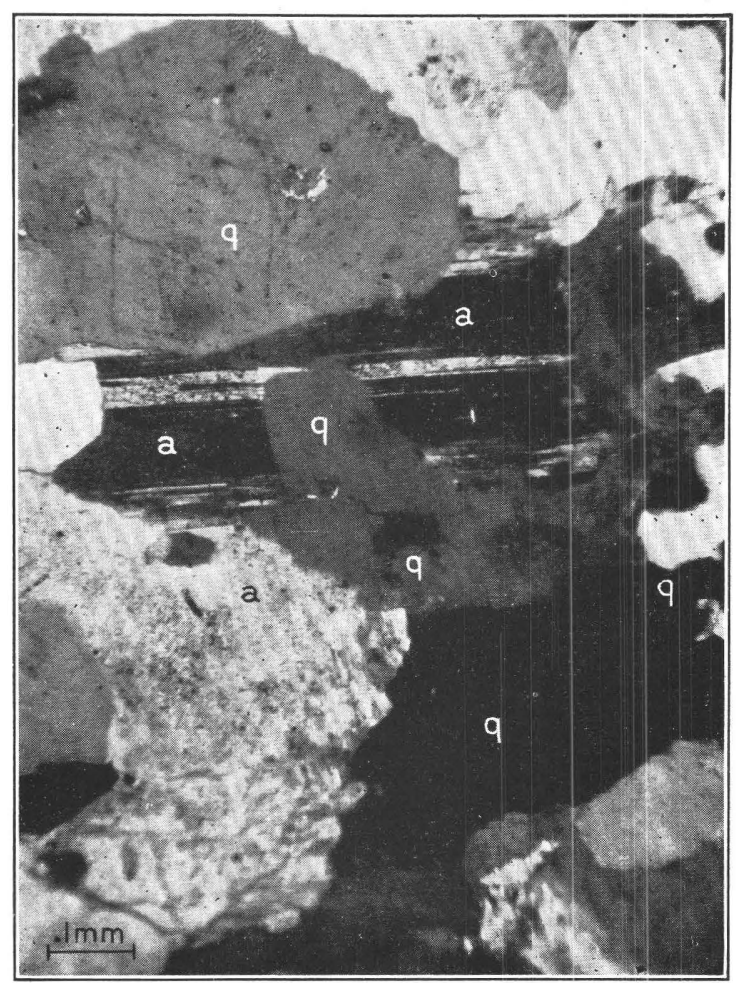

A. ALBITE CRYSTAL (a) EMBAYED BY QUARTZ (q) IN STRUCTURE INTERPRETED AS DUE TO REPLACEMENT

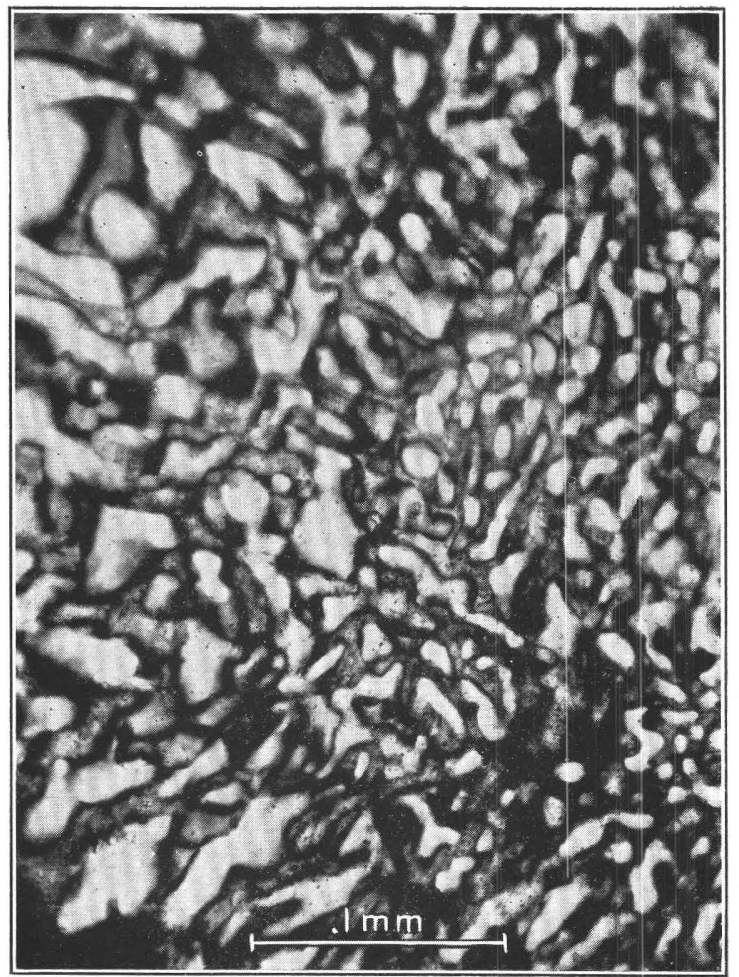

C. "BRAIN-CORAL" MYRMEKITE IN ALBITE GRANITE Dark areas albite; light areas quartz,
PROFESSIONAL PAPER 175 PLATE 19

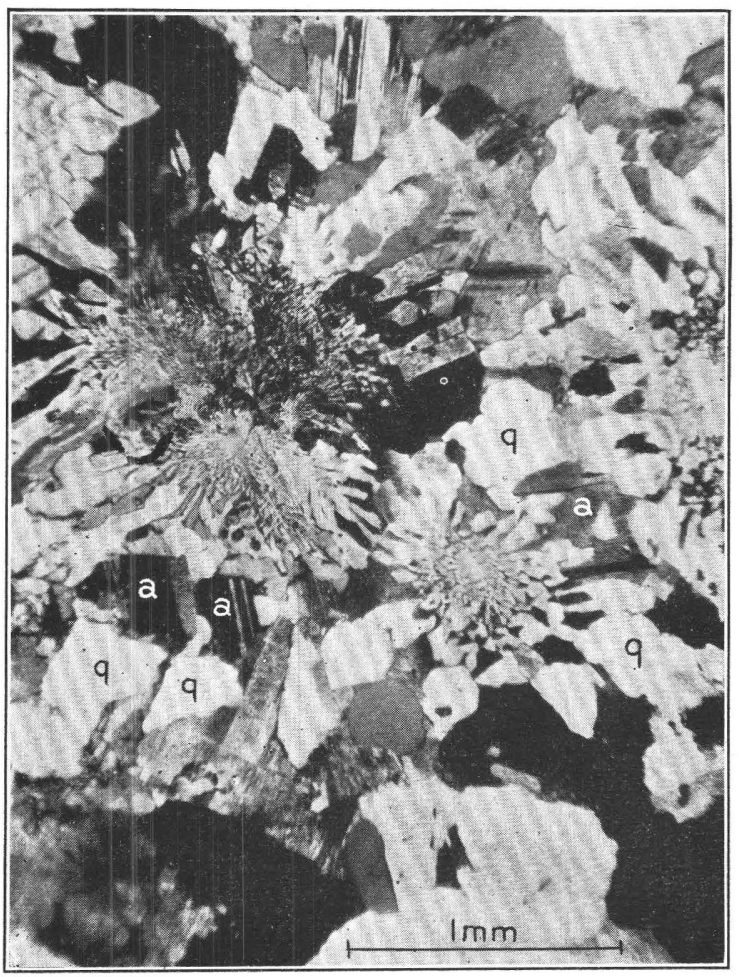

B. MicRographic TEXTURE OF ALbite GRANite a, Albite; q, quartz.

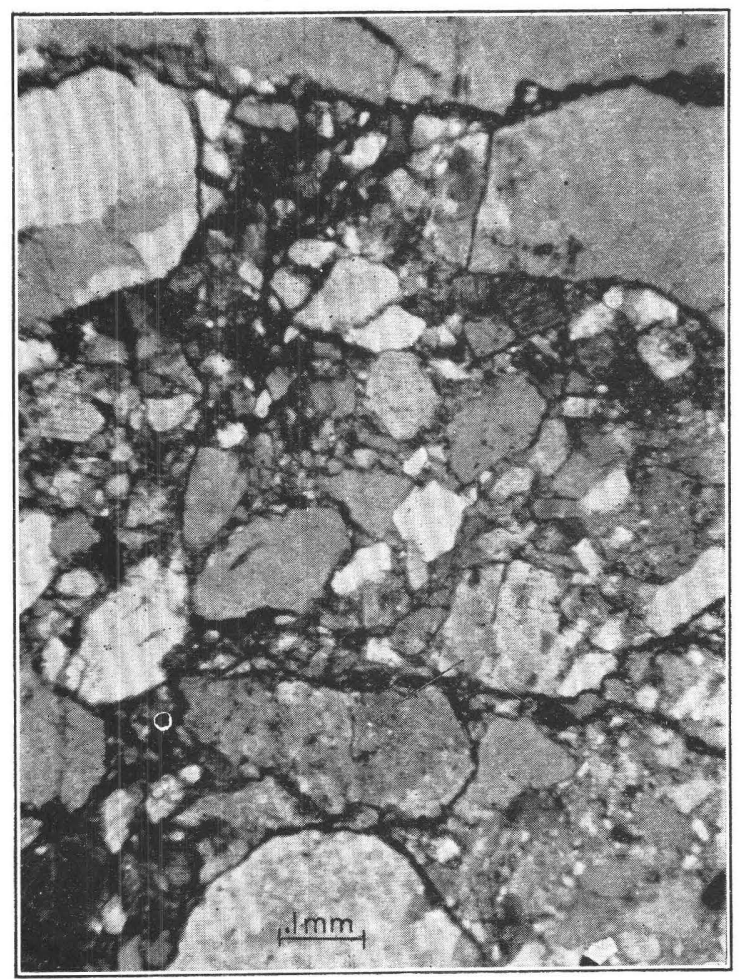

D. CATACLASTIC ALBITE GRANITE 


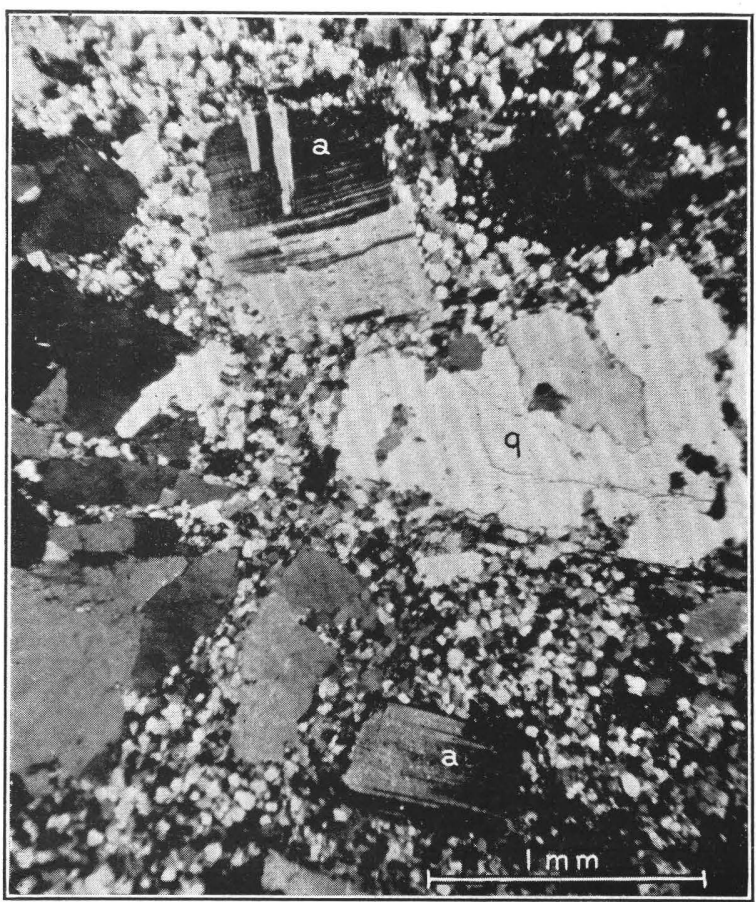

A. CATACLASTIC ALBITE GRANITE a, Albite; q, quartz.

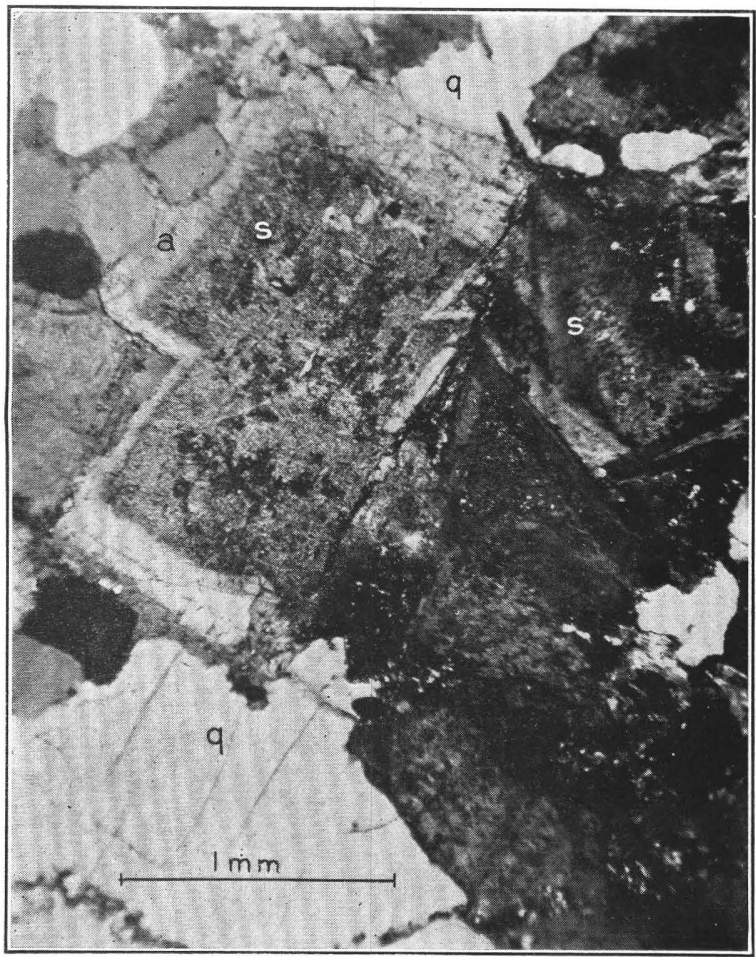

C. ALBITE GRANITE

Showing saussuritic plagioclase (s) with rim of clear albite (a) surrounding it; some sericite in the core. q, Quartz.

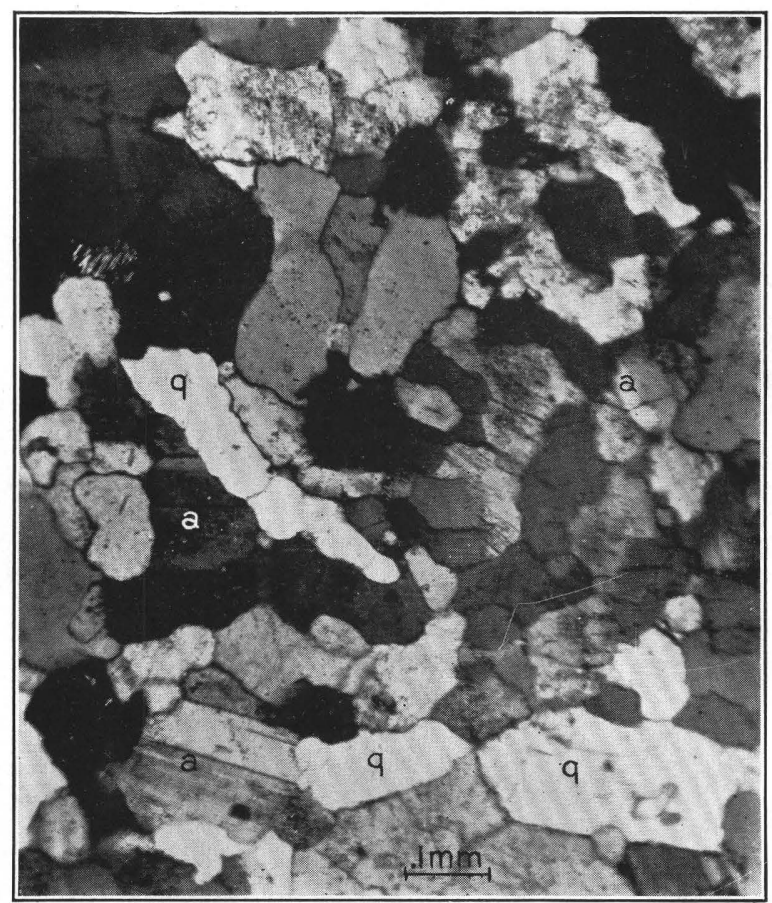

$B$. CRYSTALLOBLASTIC ALBITE GRANITE a, Albite; q, quartz.

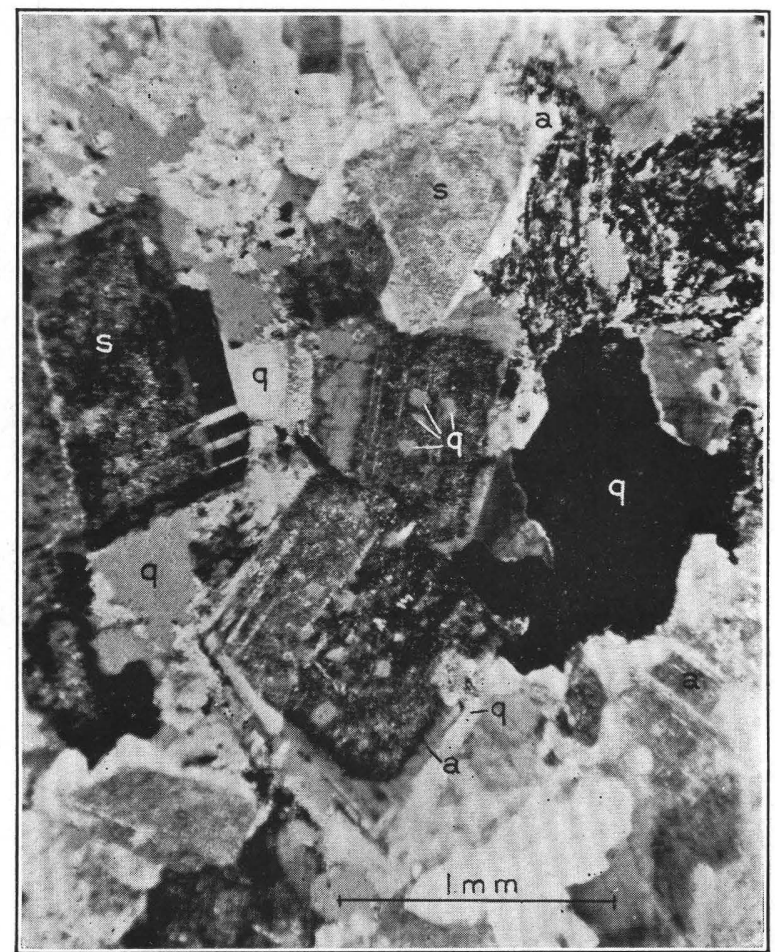

D. ALBITE GRANITE

Broken plagioclase with saussuritic center (s) and clear albite border (a) partly replaced by blebs and tongues of quartz (q). In upper 


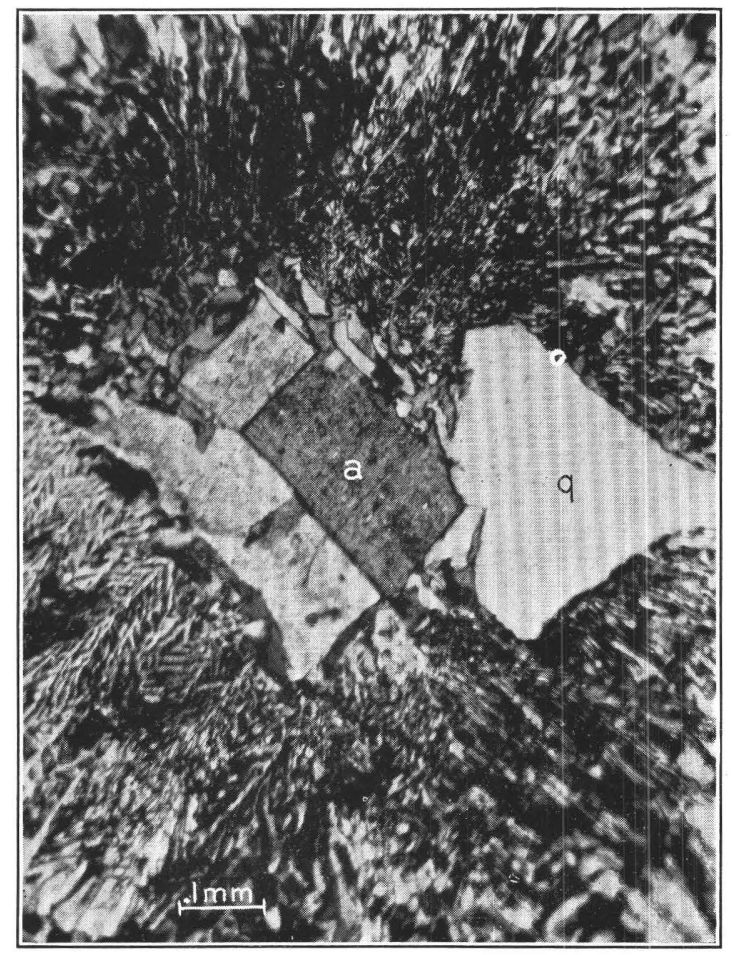

A. ALBITE (a) SURROUNDED BY MICROGRAPHIC ROSETTE OF ALBITE AND QUARTZ (q)

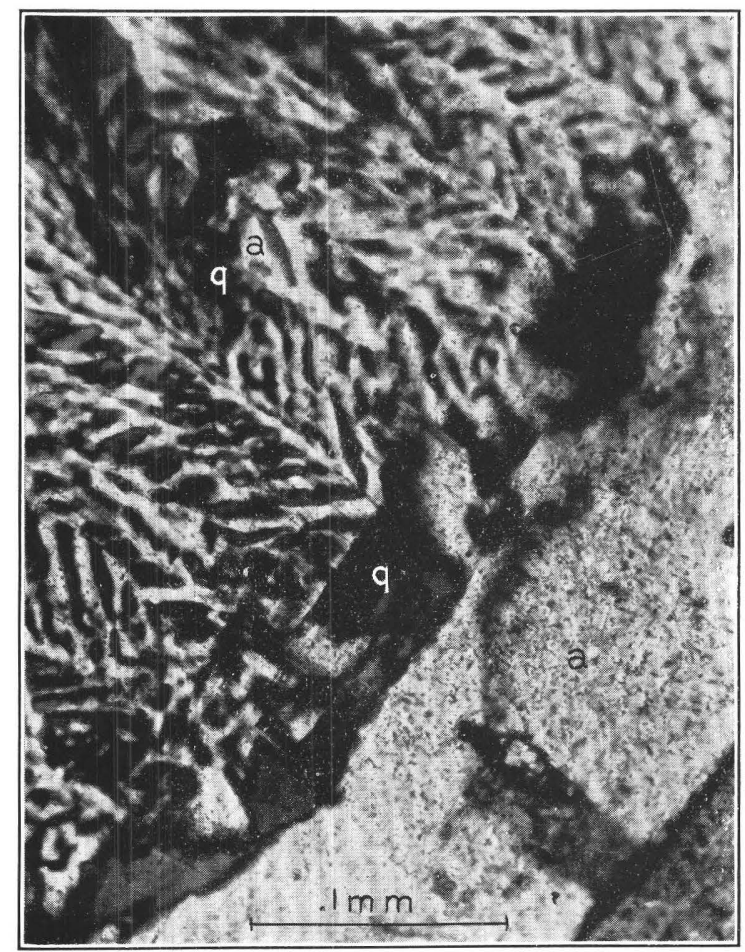

B. ENLARGED PHOTOGRAPH OF BORDER OF MICROGRAPHIC INTERGROWTH AGAINST THE CENTRAL ALBITE CRYSTAL SHOWN IN $A$

a, Albite; q, quartz.

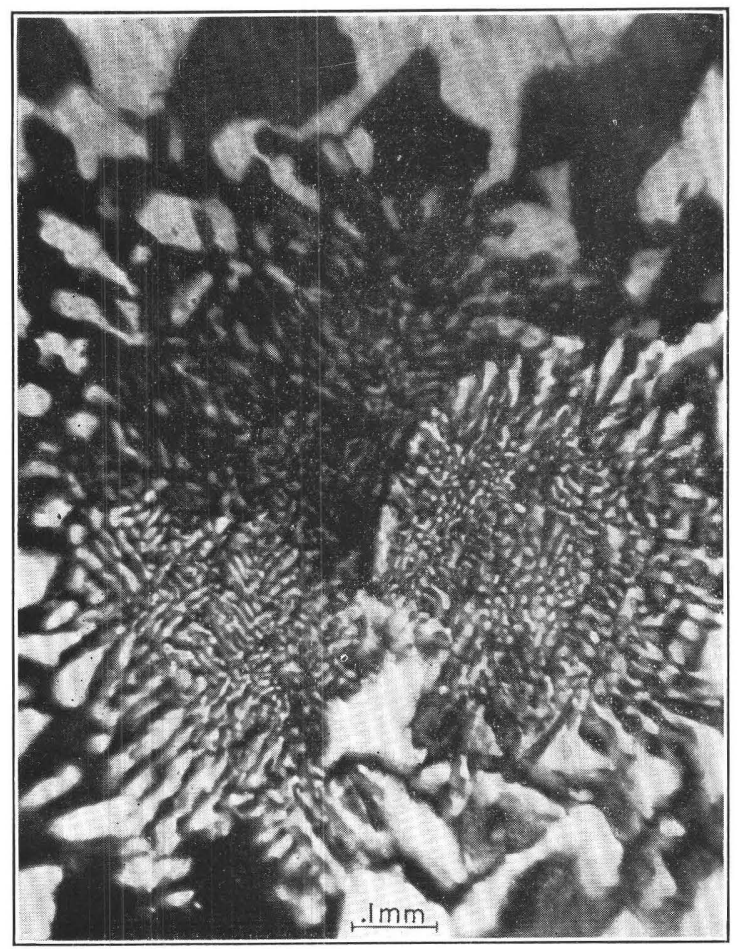

$D$ GRAPHIC INTERGROWTH OF ALBITE AND QUARTZ SHOWING SOME RESEMBLANCE TO MYRMEKITE 
U. S. GEOLOGICAL SURVEY

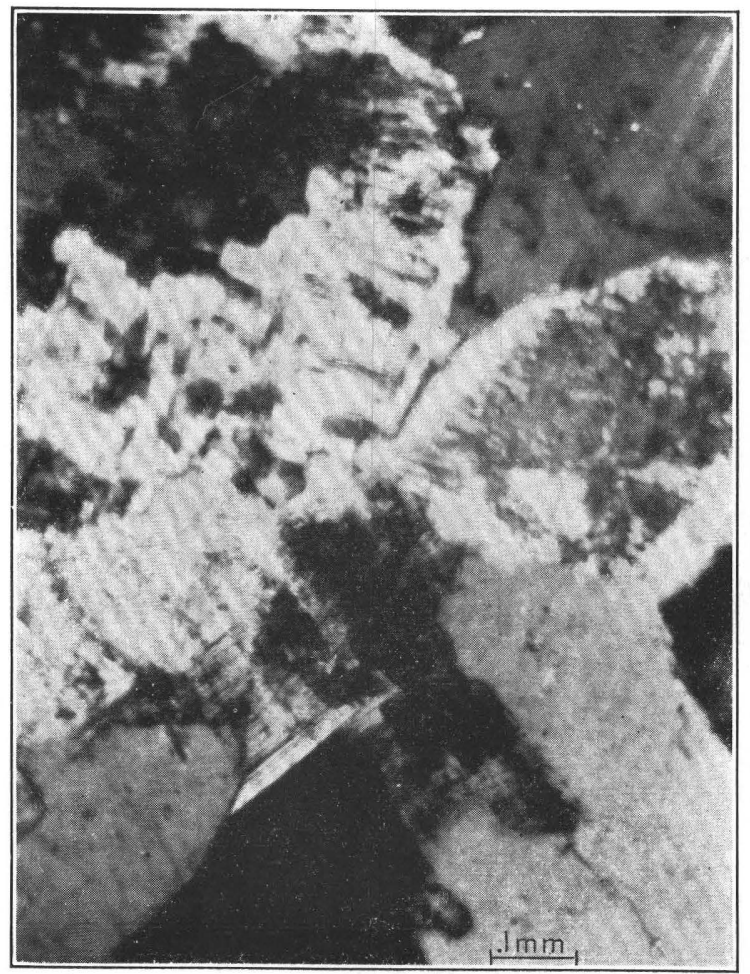

A. ALBITE SHOWING TENDENCY TOWARD CHESSBOARD STRUCTURE

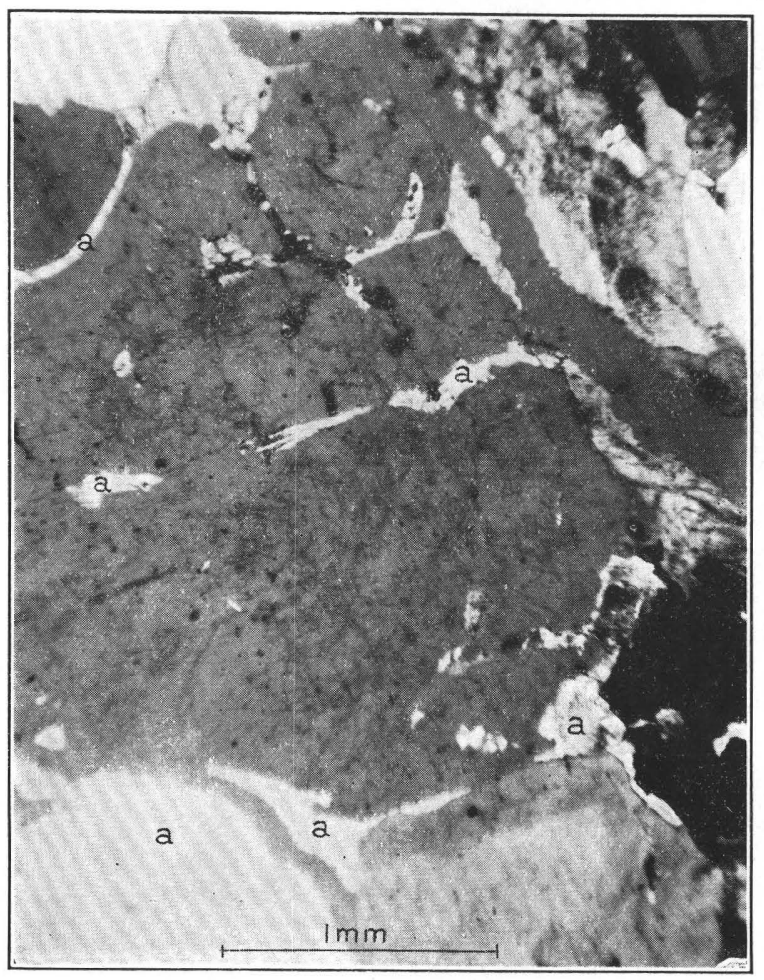

C. WISPS OF RESIDUAL ALBITE (a) IN QUARTZ WHICH IS REPLACING IT

All the albite shown extinguishes simultaneously.
PROFESSIONAL PAPER 175 PLATE 22

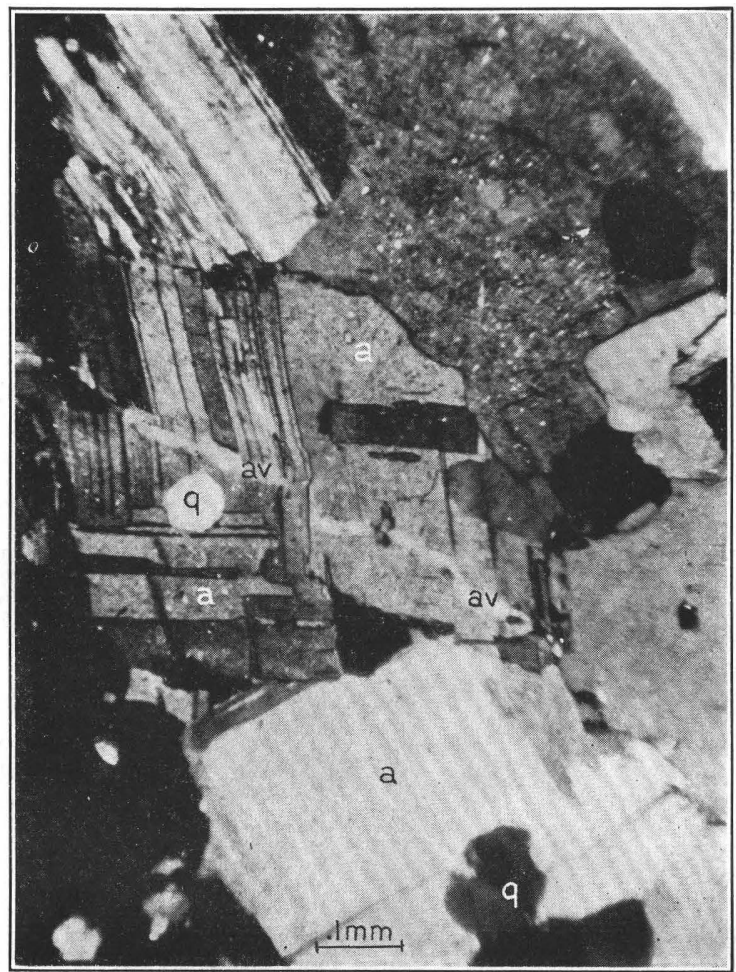

B. ALBITE GRANITE CUT BY VEINLETS OF CLEAR ALBITE av, Albite vein; a, albite; q, quartz.

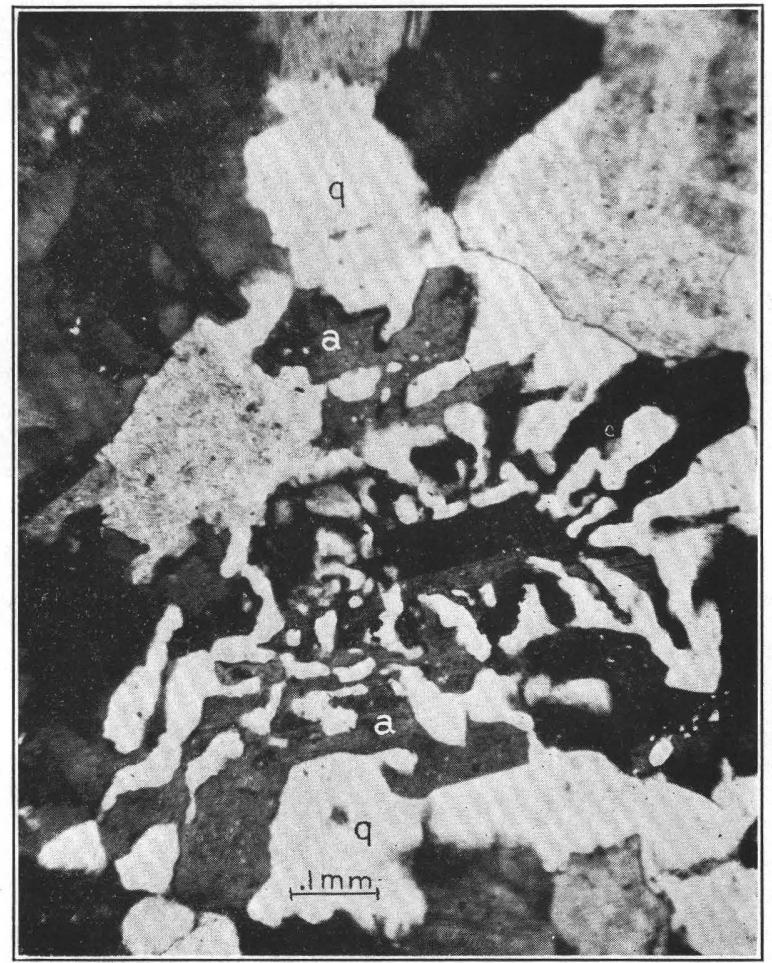

D. ALBITE CRYSTAL (a) PARTLY REPLACED BY QUARTZ (q) IN PSEUDOGRAPHIC STRUCTURE

Compare with Plate 21, $A$. 
U. S. GEOLOGICAL SURVEY

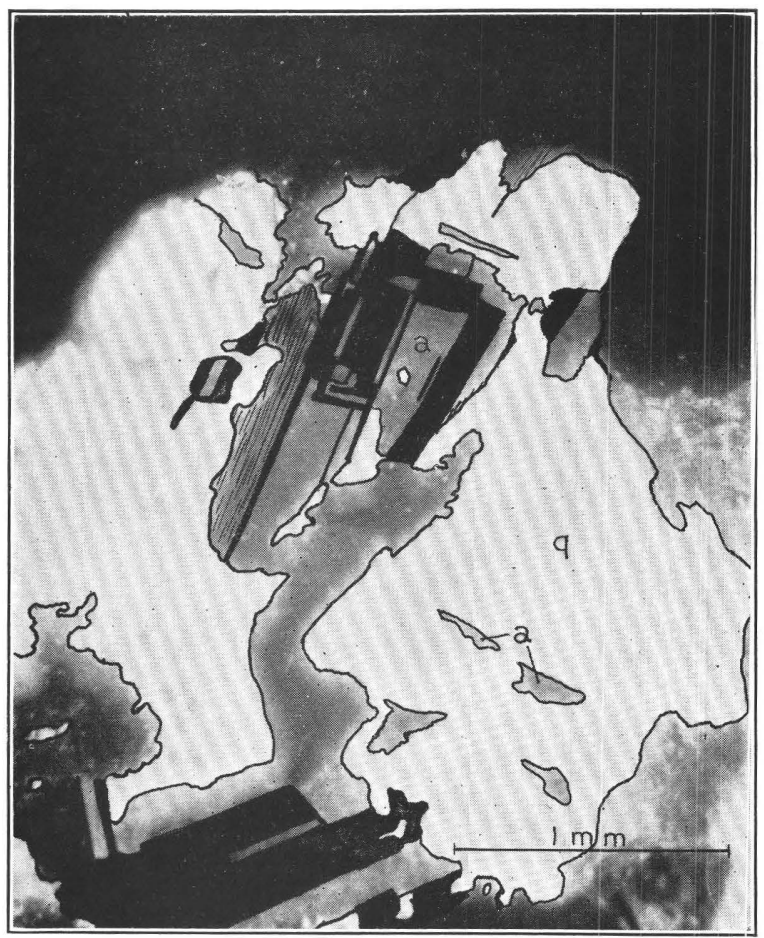

A. ALBITE (a) BEING REPLACED BY QUARTZ (q) Note the common orientation of albite wisps near the large central
crystal.

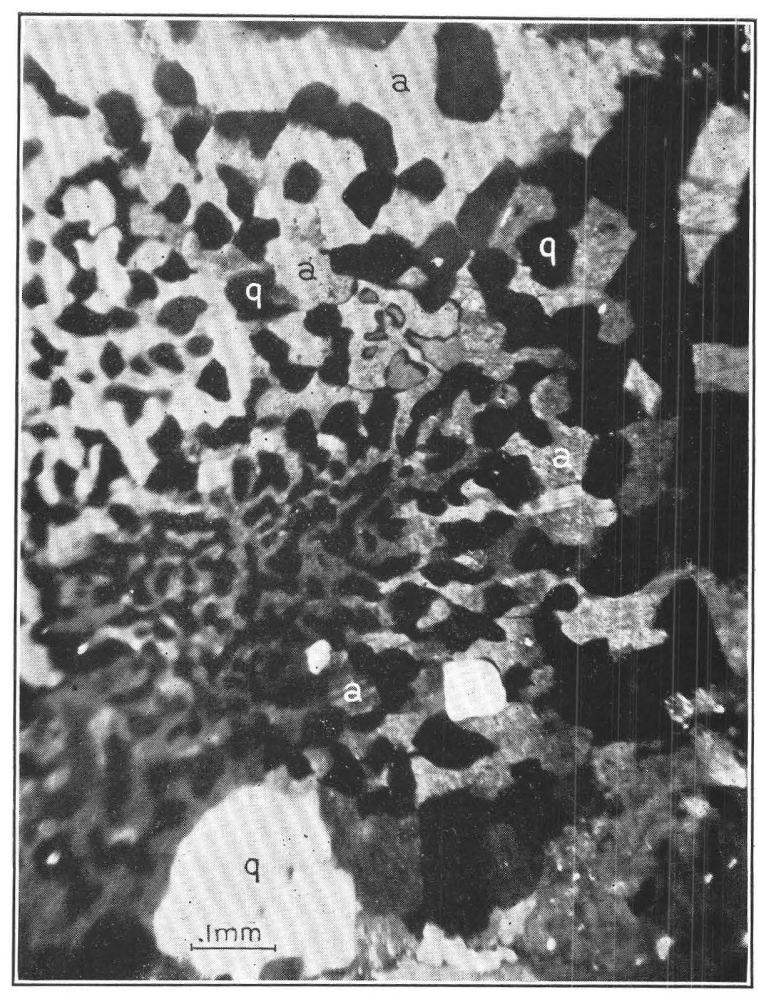

C. AlBite (a) PARTLY REPLACED BY QUARTZ (q) IN CRUDE GRAPHIC STRUCTURF
PROFESSIONAL PAPER 175 PLATE 23

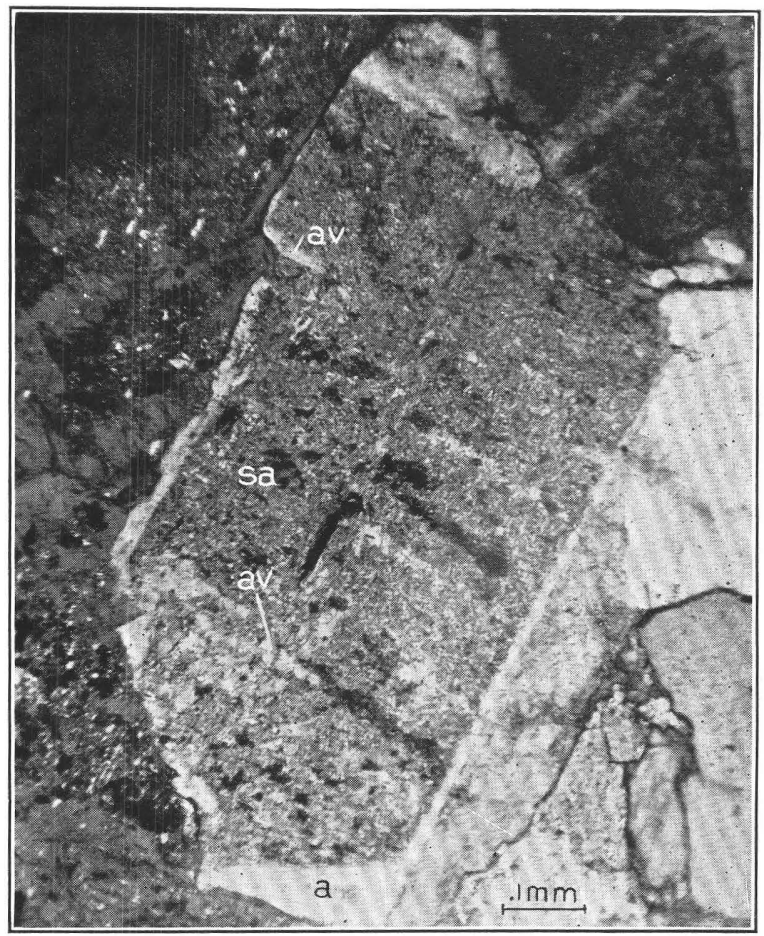

B. SERICITIC ALBITE (sa) COATED AND VEINED BY CLEAR ALBITE (a, av)

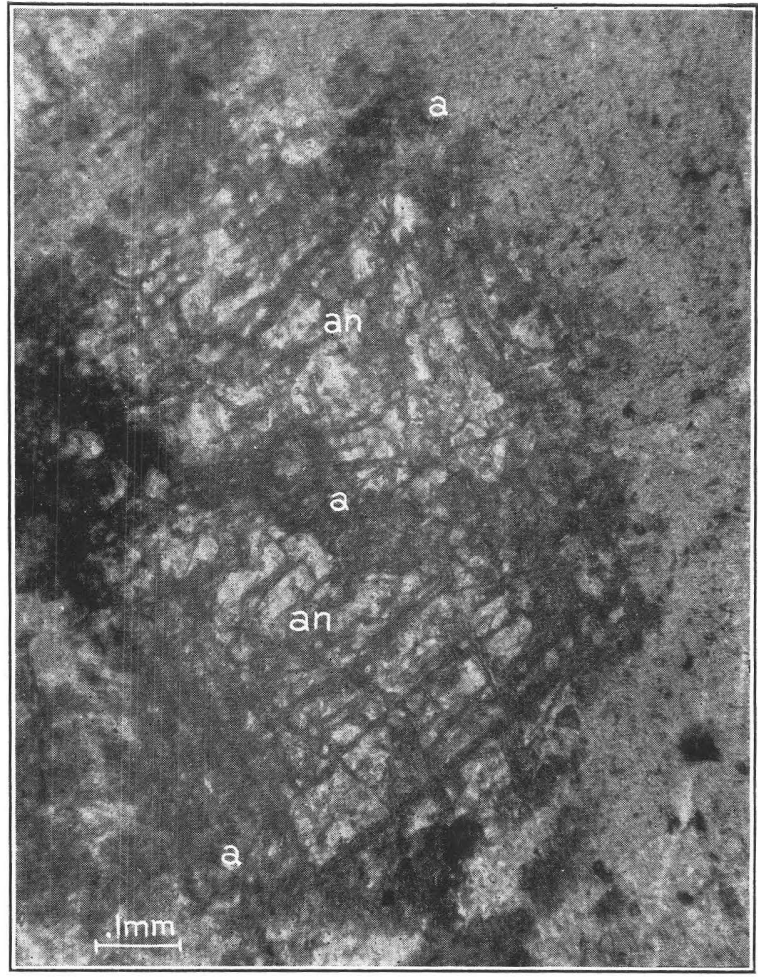

D. CENTRAL CORE OF SOMEWHAT SAUSSURITIC ANDESINE (an) SURROUNDED BY ALBITE (a) IN RELATION INTERPRETED TO SIGNIFY REPLACEMENT 
A little albite occurs in narrow veins filling cracks in the rocks. (See pl. 22, B.) Such veins pass through quartz, cloudy albite, and mafic minerals indifferently. (See p. 73.)

The albite of these rocks has extinction angles as great as $16^{\circ}$ in the zone normal to 010 , and of $18^{\circ}$ between $a^{\prime}$ and 001 in sections normal to $\gamma$. Some of it is therefore at least as sodic as $A b_{96} A_{4}$, and much of it is probably even more sodic. In many specimens the indices of refraction are all lower than 1.54, although in a few the composition is probably as calcic as $\mathrm{Ab}_{92} \mathrm{An}_{8}$.

Quartz.-The quartz of these rocks has diverse habits. Some is simply interstitial to the feldspars, as in the quartz diorite, but most of it has lobed edges against the feldspar (see pls. 19, $A ; 22, C ; 23, A$ ), and presents convex contacts toward it in very involved patterns extending through the feldspar. Some occurs in patches isolated within feldspar grains; some obviously veins and cuts all other minerals. Many of the crystals are brecciated, all gradations being seen from so-called "strain shadows" to quartz flour in some of the severely mylonitized specimens.

The quartz is notably bluish and is similar to the bluish augen quartz of many schists. The oil-immersion lens reveals many minute, very elongate needles in the quartz, and the color is doubtless due to these needles. Their identity could not be proved, but they resemble rutile.

Amphibole.-Two varieties of amphibole occur. One is apparently common hornblende, like that of the quartz diorite. It has the following optical properties: Extinction angle $21^{\circ} \gamma \wedge c$, birefringence about 0.025 , optically negative, $2 \mathrm{~V}$ moderate, $\mathrm{Z}$ bluish green, $\mathrm{Y}$ brownish green, and $\mathrm{X}$ yellowish green $\mathrm{Z}>\mathrm{Y}>\mathrm{X}$. These properties do not indicate any notable content of alkalies. However, in some specimens the common green hornblende is blotched, especially toward the ends of individual crystals, with greenish-blue patches having different optical properties. In several specimens the principal amphibole has the properties of the bluish parts of these blotched hornblendes, as follows: Extinction angle $28^{\circ} \gamma \wedge c$, birefringence low, surely less than 0.015 (the strong colors rendering its measurement difficult), optically negative, $2 \mathrm{~V}$ very small, pleochroism $\mathrm{Z}=\mathrm{Y}$ a deep greenish blue $>\mathrm{X}$, light yellow-brown. These properties agree with those of hastingsite.

Biotite--Many specimens carry small amounts of biotite of the common variety, mostly as an alteration product of hornblende, although some seems to be of independent origin. It is nowhere the dominant mafic mineral, although much more plentiful than in the quartz diorite.

Sericite.-Considerable sericite occurs in the saussuritized variety of plagioclase.

Epidote.-The dominant dark mineral in most specimens is epidote. It occurs with clinozoisite in the saussuritized plagioclase, and locally it shows a very marked tendency to develop in the central cores of the plagioclase. It also occurs as an alteration product of hornblende and as independent veins through the rock.

Subordinate minerals.-As a rule, accessory minerals are far less plentiful in the albite granite than in the quartz diorite. Among them, titanite is most abundant, iron ores next, and apatite, zircon, and rutile (?) follow in order of decreasing quantity. Chlorite is common in small quantities as an alteration product of the mafic minerals, especially in association with iron ore, after hornblende.

\section{ZONE GRADATIONAL BETWEEN QUARTZ DIORITE AND ALBITE GRANITE}

\section{FIELD RELATIONS}

At two localities - on the hillside north of the Macy mine, near the mouth of Maiden Gulch, and the hills on both sides of Goose Creek, in secs. 4, 8, 9, and 10, T. 8 S., R. 43 E.-it is possible to examine in detail the mutual relations of the quartz diorite and albite granite. At both these localities the rocks are connected by intermediate varieties so that the contact is gradational.

Near the Macy mine, in Maiden Gulch, where the exposures are somewhat more nearly complete than at Goose Creek, a zone about 1,000 feet wide shows a passage from dark-gray, almost quartz-free diorite to light-gray, highly quartzose albite granite. The transition is gradual, being marked first by increasing quantities of quartz, appearing along breccia surfaces, then by increasing quantities of biotite relative to hornblende (although the total quantity of mafic minerals is declining), then by the appearance of bluish quartz grains in the mass of the rock, and finally by the marked diminution of dark minerals and a corresponding increase of light minerals throughout the rock. At the Maiden Gulch locality the extreme variety of albite granite, such as is widely developed near Goose Creek and especially near the Gem mine at Sparta, is not found. This variety is pseudoporphyritic and contains great quantities of quartz in blebs as much as 2 centimeters in diameter and numerous connecting veinlets, in a matrix consisting of rather coarse greenish plagioclase and almost negligible quantities of biotite and amphibole.

Gradations between the Maiden Gulch variety and the pseudoporphyritic variety are to be found both near Sparta and near Goose Creek. The Goose Creek transition zone is less completely exposed than that of Maiden Gulch, but identical transition features are to be found there.

\section{LITHOLOGY}

The microscope confirms the conclusion drawn from field studies, that the quartz diorite is gradational to the albite granite. Microscopic features of typical 
quartz diorite and albite granite have been described. The features recognized under the microscope in specimens from the contact zone include, in passing from the diorite to the granite, (1) an increase in the quantity of quartz, which locally reaches extremes of fully 50 per cent, and a change from an interstitial habit to lobate and penetrative forms toward the feldspar; (2) a change in the plagioclase, in some specimens merely to saussurite, in others by the development of clear albite rims about saussurite cores, in still others by the development of tonguelike protuberances of albite in but slightly altered andesine; (3) a change in the hornblende by partial alteration to biotite and by the spotty development of hastingsite both internally and at the ends of crystals; (4) a marked decrease in the total quantity of mafic minerals; (5) a change in the accessory minerals by marked decrease of all except rutile (?), which makes its appearance in quartz.

Concomitant with these mineralogic changes are textural changes in the direction of decrease in simple granitic texture (hypidiomorphic granular) and marked increase in cataclastic, myrmekitic, and micrographic textures. Crystalloblastic texture is rare and is apparently confined to the albite granite, as it is not present in any transition rocks examined. This limitation may be of genetic significance.

\section{CHEMICAL FEATURES}

The field relations of the albite granite and quartz diorite taken together with the microscopic features just summarized have led to the conviction that the two rocks are most intimately related and are connected by a complete transition series. To test this question further, chemical analyses were made of representative specimens of the quartz diorite and albite granite and of two intermediate rocks. These analyses seem to show that there is an almost complete gradation between the two end members.

Analyses of quartz diorite, albite granite, and transitional phases [J. G. Fairchild, analyst]

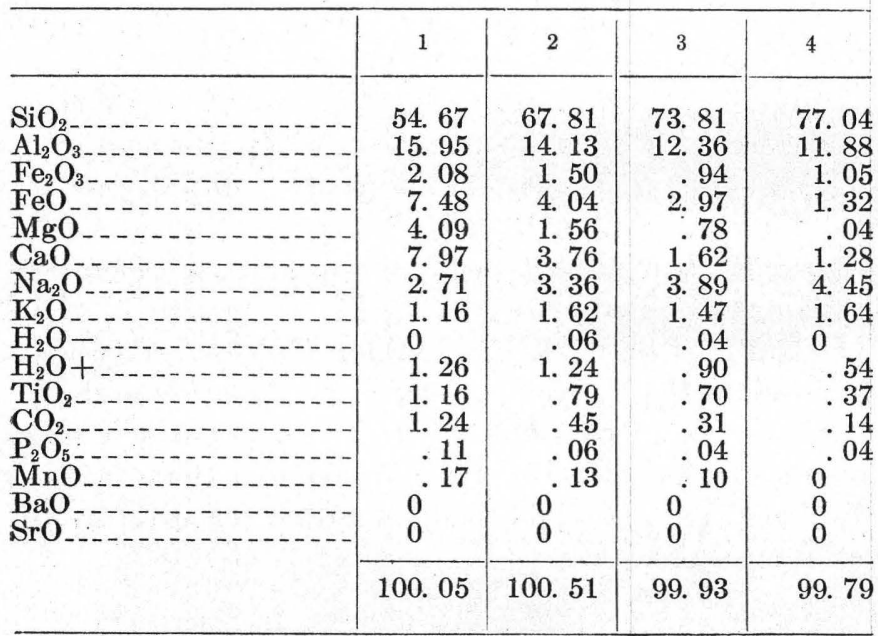

1. Quartz diorite, sec. 9, T. 8 S., R. 43 E.

2. Partly albitized quartz diorite, same locality

3. Pseudoporphyritic albite granite, sec. 8, T. 8 S., R. $43 \mathrm{E}$.
4. Pseudoporphyritic albite granite, sec. 13, T. 8 S., R. $43 \mathrm{E}$.
The norms, computed in accordance with the classification of Cross, Iddings, Pirsson, and Washington, are as follows:

\begin{tabular}{|c|c|c|c|c|}
\hline & 1 & 2 & 3 & 4 \\
\hline 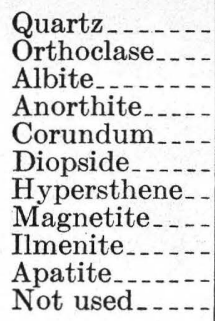 & $\begin{array}{r}10.50 \\
7.23 \\
23.06 \\
27.80 \\
3.00 \\
19.14 \\
3.02 \\
2.28 \\
.34 \\
2.50\end{array}$ & $\begin{array}{r}30.04 \\
9.45 \\
28.30 \\
17.79 \\
.31\end{array}$ & $\begin{array}{r}\text { 40. } 48 \\
8.90 \\
\text { 33. } 01 \\
7.23 \\
1.73\end{array}$ & $\begin{array}{r}42.12 \\
9.45 \\
37.73 \\
5.56 \\
.82\end{array}$ \\
\hline & 98.87 & 100.06 & 100.85 & 100. 13 \\
\hline Symbol_...... & II.4(5).(3) 4.4 & (I) II. (3) 4.3 .4 & $I^{\prime \prime} .3 .2 .4$ & I.3.' ${ }^{\prime \prime 2.4}$ \\
\hline
\end{tabular}

These analyses have been recomputed into modal minerals on the basis of the microscopic study of the rocks. The textures of the rocks are not favorable to accurate measurements by the Rosiwal method, but the computed mineral composition agrees fairly well with the estimated proportions observed.

Approximate mineral composition of quartz diorite, albite granite, and transition rock

\begin{tabular}{|c|c|c|c|c|}
\hline & 1 & 2 & 3 & 4 \\
\hline \multirow{14}{*}{$\begin{array}{l}\text { Quartz } \\
\text { Albite } \\
\text { Anorthite } \\
\text { Orthoclase } \\
\text { Hornblende } \\
\text { Hastingsite } \\
\text { Epidote } \\
\text { Biotite } \\
\text { Sericite } \\
\text { Titanite } \\
\text { Ilmenite } \\
\text { Magnetite. } \\
\text { Chlorite } \\
\text { Calcite } \\
\text { Apatite. } \\
\end{array}$} & 12 & & 42 & 41 \\
\hline & 23. 5$\} 40$ & $\{28\} 34$ & $\left\{\begin{array}{c}26 \\
2\end{array} 29\right.$ & $\{38.5\} 40$ \\
\hline & 16. $5 \int^{ \pm 0}$ & $\left\{6 \int^{2 x}\right.$ & $\left\{3 \int_{4}^{20}\right.$ & $\left\{1.5 \int^{x-5} 5\right.$ \\
\hline & 26 & 11. 5 & 8 & .5 \\
\hline & $-\cdots$ & .5 & 1. 5 & .5 \\
\hline & $\begin{array}{l}3 \\
1\end{array}$ & $\begin{array}{l}2.5 \\
5\end{array}$ & 4. 5 & 4. 5 \\
\hline & & $\begin{array}{l}{ }_{2} \\
\end{array}$ & 5 & 5 \\
\hline & 2 & 1 & 1 & .5 \\
\hline & 1 & 1 & 1 & .3 \\
\hline & 2 & 2 & .5 & .5 \\
\hline & 2. 5 & 1 & 2. 5 & .7 \\
\hline & 3 & 1 & .7 & \\
\hline & .5 & .5 & .1 & .1 \\
\hline & 100. 0 & 100.0 & 99.8 & 100.4 \\
\hline
\end{tabular}

a Most of the potash feldspar is occult, probably in solution in the plagioclase.

\section{CONCLUSIONS RESPECTING RELATIONSHIP}

All the lines of evidence cited-field, microscopic, and chemical-are believed to point to a complete gradation between the diorite and the albite granite. The transition from one rock to the other can be traced in the field relations, in the mineralogy, in the texture, and in the chemical composition. Moreover, the continuity of the transition implies that the differences between the two facies arose in place and did not result directly from differentiation at depth. The direct relation between the intensity of the crushing of a rock and the increase in the quantity of the minerals characteristic of the albite granite (quartz, albite, and hastingsite) which it possesses is further evidence in favor of a derivation of the albitic rock in place, for 
it suggests that the modifications took place in the rock after it became solid. Moreover, it suggests strongly that the albite granite is an albitized and silicified facies of the quartz diorite and that the albitization was localized by zones of brecciation along which silica and soda-bearing solutions gained ready access to large volumes of rock. According to this suggestion, the albite granite is the product of metamorphic replacement localized through mechanical openings that were due to orogenic processes.

Several features in the rocks point toward such an origin of the albite granite, and none that are known to the writer are out of harmony with such an origin. The evidence afforded by the texture and mineralogy of the rocks, so far as their bearing upon the genesis was recognized, is discussed in the following sections.

\section{EVIDENCE OF LATE MAGMATIC OR HYDROTHERMAL MINERAL FORMATION \\ TEXTURAL EVIDENCE}

The cataclastic features of the albite granite could have been developed only after nearly complete consolidation of the rock. The cataclastic rock shows in some places nonsaussuritic, in many places only slightly saussuritic, albite crystals of sizes and shapes and having zonal arrangements of inclusions which are nearly identical with those of the andesine crystals of the quartz diorite. That these crystals are pseudomorphs after the andesine of the diorite is bighly probable. This strongly suggests postmagmatic albitization, although the observation in itself does not prove that the albitization accompanies the brecciation. These feldspars differ from the saussurite pseudomorphs occurring in some of the rocks transitional to the quartz diorites, although even these saussuritic feldspars are probably due to hydrous solutions, ${ }^{9}$ inasmuch as zoisite is a hydrous silicate, and they suggest, if they do not demand, dynamic processes for their formation. ${ }^{10}$ Chemical evidence proves, however, that even the saussuritic feldspar of the albite granite differs notably in bulk composition from that of the quartz diorite. (See norms on p. 70.)

Some of these transition rocks yield other specimens in which only slightly altered andesine is inclosed by clear albite, with irregular contacts involving marked embayment of the andesine core by the surrounding albite. These specimens strongly suggest attack by sodic solutions on the earlier andesine and its partial replacement by albite, for the relation is not mere zoning and the phase relations of the plagioclase system prohibit the coexistence in contact of albite and andesine in equilibrium. ${ }^{11}$ The albite pseudomorphs after andesine are believed to represent the end stage of this replacement process. Similar

${ }^{\ominus}$ Grubenmann, U., and Niggli, P., Die Gesteinsmetamorphose, I, p. 317, Berlin, 1924.

10 Smirnoff, N., Recherches sur l'albitisation des roches éruptives: Arch. sci. phys. nat., vol. 37, pp. 512-528, Genève, 1914.

${ }^{11}$ Bowen, N. L., The evolution of the igneous rocks, p. 34, Princeton, 1928. $137047^{\circ}-33-2$ structures in basaltic lavas, involving calcic plagioclase cores and albite rims, have been attributed to albitization replacement by Bailey and Grabham. ${ }^{12}$ Gillson ${ }^{13}$ has noted in two localities labradorite cores surrounded by irregular andesine borders and penetrations which he interpreted as evidence of replacement. Similar observations have been made by Kinoshita. ${ }^{14}$ The relations exhibited in the Sparta rocks are shown in Plate 23, D. Holmquist has described similar replacements of calcic feldspars by sodic ones, interpreting them as reaction products of inclusions. ${ }^{15}$

Myrmekite is recognized as a replacement product in both metamorphosed and unmetamorphosed rocks. ${ }^{16}$ Tronquoy ${ }^{17}$ has suggested that it is the result of a special mode of albitization, which he refers to "autopneumatolysis," after consolidation of the rock. He points out that myrmekite, though favoring the contacts between plagioclase and microcline, is not limited to such contacts, but may occur, contrary to the dictum of Becke, ${ }^{18}$ on the contact between two microcline crystals or even on the contact with quartz..$^{19} \mathrm{He}$ accordingly suggests that it is localized by accidental openings through which the albitizing solutions gain access to the microcline crystals. Mechanical as well as chemical factors thus play parts in localizing the myrmekite, and it is for this reason, in the opinion of Tronquoy, that slightly cataclastic rocks, as has long been recognized, furnish especially favorable environments for myrmekite. Inasmuch as the special form of albitization represented by myrmekite occurs in conjunction with the chemical and mineralogical transitions previously described, the existence of at least some albitizing solutions in the albite granite is demonstrated. A local source of the soda and silica in myrmekite formation has been generally accepted, possibly with some justification, but Sederholm ${ }^{20}$ admits and Tronquoy ${ }^{21}$ demands the presence of circulating alkalic solutions of extraneous source in its formation. In the present occurrence the marked association of the myrmekite with the cataclastic albite granite, with soda-bearing amphibole, and with

${ }^{12}$ Bailey, E. B., and Grabham, G. W., Albitization of basic plagioclase feldspars: Geol. Mag., dec. 5, vol. 6, pp. 250-256, 1909.

${ }^{13}$ Gillson, J. L., Petrography of the Pioche district, Nevada: U. S. Geol. Survey Prof. Paper 158, p. 80, 1929. Gillson, J. L., and Kania, J. E. A., Genesis of the emery deposits near Peekskill, N. Y.: Econ. Geology, vol. 25, pp. 514-515, 1930.

14 Kinoshita, K., On the "Kurokô" (black ore) deposits: Japanese Jour. Geology and Geography, vol. 8, p. 295, 1931 .

${ }_{15}$ Holmquist, P. J., Studien über die Granite von Schweden: Geol. Inst. Upsala Bull., vol. 7, pp. 157, 165, pl. 17, fig. 9, 1906.

${ }^{16}$ Sederholm, J. J., On synantetic minerals and related phenomena: Comm. géol. Finlande Bull., vol. 9, No. 48, p. 139, 1916.

${ }_{17}$ Tronquoy, R., Origine de la myrmekite: Soc. française minéralogie Bull., vol. 35 , pp. 221-222, 1912.

18 Becke, F., Über Myrmekit: Min. pet. Mitt., Band 27, p. 381, 1908.

${ }_{19}$ See also Tschirwinsky, Peter, Quantitative mineralogische und chemische Zusammensetzung der Granite und Greisen, pp. 673-674, Moscow, 1911, wholikewise questions Becke's dictum. Gerald Andrew (The contact relations of the Donegal granite, Irish Free State: Manchester Lit. and Philos. Soc. Mem. and Proc., vol. 72, p. 215,1928$)$ describes myrmekite in plagioclase, which supports Tronquoy's idea that the production of myrmekite is a special form of albitization and is not dependent on local material only.

${ }^{20}$ Sederholm, J. J., On migmatites and associated pre-Cambrian rocks of southwestern Finland: Comm. géol. Finlande Bull., vol. 12, No. 77, p. 131, 1926.

${ }^{21}$ Tronquoy, R., op. cit., p. 221. 
quartz that is dominantly lobate toward the plagioclase strongly suggests that it was formed by introduced solutions not derived from immediately contiguous parts of the mass.

The micrographic texture that is so common in the albitic rocks is not clearly distinguishable in all phases from the myrmekitic texture. Similar difficulty in distinguishing them has been experienced by Tschirwinsky ${ }^{22}$ and by Bergt. ${ }^{23}$ Goldschmidt ${ }^{24}$ has described a "pseudogranophyric" texture resulting from endstage replacement of potash feldspar by myrmekite. Gradations from normal graphic intergrowth into "quartz vermiculé" (myrmekite) in the Bathgate and Linlithgow Hills, Scotland, are described by Falconer, ${ }^{25}$ who regards some of the graphic intergrowth as doubtless replacing earlier feldspar. Although many other writers express confidence that the two textures have nothing in common,,$^{26}$ and certainly no one can fail to recognize the differences between the typical developments of the two, the present writer can not escape the belief that the tendency to view them as readily distinguishable in all aspects and of entirely distinct conditions of origin is due in large part to the dominance of the view, first tentatively suggested by Teall, that graphic textures are the result of eutectic crystallization ${ }^{27}$ and hence can have nothing in common with the myrmekitic intergrowths, which are universally accepted as replacement phenomena.

The view that graphic textures are conclusive evidence of eutectic intergrowth has many strong adherents even at the present time, ${ }^{28}$ although the idea has been severely criticized by Judd, ${ }^{29}$ Mennell, ${ }^{30}$ Collins, ${ }^{31}$ Warren and Palache, ${ }^{32}$ Bastin, ${ }^{33}$ Fenner, ${ }^{34}$

\footnotetext{
22 Tschirwinsky, Peter, cited by Tronquoy, R., op. cit., p. 215.

${ }^{23}$ Bergt, W., quoted by Becke, F., op. cit., p. 380.

${ }_{24}$ Goldschmidt, V. M., Übersicht der Eruptivgesteine im kaledonischen Gebirge zwischen Stavanger und Trondhjem: Vidensk. Skrifter, I, Mat.-Naturv. Klasse, 1916, No. 2, p. 78.

${ }^{25}$ Falconer, J. D., Igneous geology of the Bathgate and Linlithgow Hills: Roy. Soc. Edinburgh Trans., vol. 45, pp. 144-145, 1908.

${ }^{26}$ Sederholm, J. J., op. cit., p. 70 . Becke, F, op. cit., p. 380 . Tronquoy, R., op. cit., pp. 217-219.

${ }_{27}^{27}$ Teall, J. J. H., British petrography, p. 401, 1886. Vogt, J. H. L., Die Silikatschmelzlösungen, I: Vidensk Skrifter, I, Mat.-Naturv. Klasse, 1903, No. 8, p.103; On the terms eutectic, etc., and their importance in petrogenesis: Jour. Geology, vol. 39, pp. 422-424, 1931. Brögger, W. C., Die Mineralien der Syenitpegmatitgänge der südnorwegischen Augit und Nephelinsyenite: Zeitschr. Kryst. Min., Band 16, 1890, p. 148. Harker, Alfred, Natural history of the igneous rocks, pp. 171, 271-272, 297, London, 1909. Iddings, J. P., Igneous rocks, 2d ed., vol. 1, p. 210, New York, 1920. Rosenbusch, Harry, Elemente der Gesteinslehre, 4th ed., by A. Osann, p. 302, Stuttgart, 1923.

${ }_{28}$ Vogt, J. H. L., The physical chemistry of the crystallization and magmatic differentiation of igneous rock. Jour. Geology, vol. 29, p. 324, 1921. Tschirwinsky, Peter, op. cit., pp. 672-674; Anchi-stoichiometrische Typen der Biotitgranite nach ihrem theoretischen Feldspatgemische geordnet: Neues Jahrb., Beilage-Bd. 53A, pp. 209-228, 1926.

${ }^{29}$ Judd, J. W., On the growth of crystals in igneous rocks after their consolidation: Geol. Soc. London Quart. Jour., pp. 175-186, 1889.

${ }^{30}$ Mennell, F. P., Basic dykes and rock genesis: Geol. Mag., dec. 5, vol. 8, pp. 14-15, 1911.

31 Collins, W. H., Onaping map area: Canada Geol. Survey Mem. 95, pp. 59-62, 1917.

${ }_{32}$ Warren, C. H., and Palache, Charles, The pegmatites of the riebeckite-aegirite granite of Quincy, Mass., U. S. A., their structure, minerals, and origin: Am. Acad. Arts and Sci. Proc., vol. 47, p. 147, 1911.

${ }^{33}$ Bastin, E. S., Origin of the pegmatites of Maine: Jour. Geology, vol. 18, p. 312, 1910.

34 Fenner, C. N., The Katmai magmatic province: Jour. Geology, vol. 34, pp. 750-754, 1926.
}

and many other petrologists. A replacement origin for some graphic intergrowths has been proved by their presence in certain adinoles, ${ }^{35}$ and Schaller ${ }^{36}$ has given reason to suspect a replacement origin of the structure in some pegmatites. The possibility of a replacement origin of the structure has also been suggested by Aurousseau ${ }^{37}$ for granophyres. Many mineragraphers have in recent years questioned the eutectic origin of this structure in ore minerals. ${ }^{38}$ Although Tyrell regards some graphic textures as of eutectic origin, he agrees that they can form in other ways. $^{39}$

Sugi ${ }^{40}$ has recently given very suggestive evidence of a replacement origin for some micrographic intergrowths in certain Japanese injection rocks. Beskow ${ }^{41}$ finds the texture in some albite granite migmatites in Sweden. Wells and Wooldridge ${ }^{42}$ have interpreted micropegmatite in a granophyre on the island of Jersey as in part of eutectic origin and in part due to late replacement by silica. Where the replaced feldspar is albite the resulting product is "myrmekite."

Similarly, the writer regards some of the graphic intergrow ths seen in the Sparta rocks, especially such as are illustrated in Plate 21, $A, B$, where the intergrowth is clearly perched on a well-developed crystal face of albite, to be due to simultaneous crystallization of quartz and albite. Other areas of similar intergrowth, however, even the inner zone of the same intergrowth, as in Plate $21, B$, appear to be clearly due to replacement-so that the structure is not in itself evidence of any particular mode of origin.

It is by no means an objective of this paper to suggest that graphic tecture is a criterion of replacement. On the contrary, it seems probable that the texture may be formed in any of at least four ways: (1) By simultaneous intergrowths not in eutectic proportions, ${ }^{43}$ (2) by eutectic crystallization, ${ }^{44}$ (3) by unmixing of solid

35 Gillson, J. I, Granodiorites in the Pend Oreille district of northern Idaho: Jour. Geology, vol. 35, p. 8, 1927. Daly, R. A., Secondary origin of certain granites: Am. Jour. Sci., 4th ser., vol. 20, p. 190, 1905.

${ }_{36}$ Schaller, W. T., The genesis of lithium pegmatites: Am. Jour. Sei., 5th ser., vol. 10, p. 276,1925

${ }^{37}$ Aurousseau, M., Analyses of three Australian rocks: Linnean Soc. New South Wales Proc,, vol. 51, p. 623, 1926. See also Falconer, J. D., op. cit.

${ }^{38}$ Whitehead, W. L., The paragenesis of certain sulphide intergrowths: Econ. Geology vol, 11, pp. 1-13, 1916. Rogers, A. F., The so-called graphic intergrow th of bornite and chalcocite: Econ. Geology, vol, 11, pp. 582-593, 1916. Guild, F. N., A microscopic study of the silver ores: Econ. Geology, vol. 12, pp. 313-314, 1917. Lindgren, Waldemar, Mineral deposits, 3d ed., pp. 209, 926, New York, 1928; Pseudoeutectic textures: Econ. Geology, vol. 25, pp. 1-13, 1930. Schwartz, G. M., and Park, C. F., jr., Pseudo-eutectic textures: Econ. Geology, vol. 25, pp. 658-663, 1930. Bastin, E. S., and others, Criteria of age relations of minerals: Econ. Geology, vol.26, pp. 571-575, 1931.

39 Tyrell, G. W., The principles of petrology, p. 64, New York, 1927.

40 Sugi, K., On the granitic rocks of the Tsukuba district and their associated injection rocks: Japanese Jour. Geology and Geography, vol. 8, pp. 65-67, 1930.

${ }^{41}$ Beskow, Gunnar, Södra Storfjället im südlichen Lappland, eine petrographische und geologische Studie im zentralen Teil des Skandinavischen Hochgebirges: Sveriges geol. Undersökning Årsbok 21, No. 5, ser. G, No. 350, pp. 161-165, 1927.

${ }^{42}$ Wells, A. K., and Wooldridge, S. W., The rock groups of Jersey, with special reference to intrusive phenomena at Ronez: Geologists Assoe. Proc., vol. 42, p. 211, 1931.

43 Bastin, E. S., and others, Econ. Geology, vol. 26, p. 574, 1931.

${ }_{44}$ Vogt, J. H. L., op cit., 1903. Loewinson-Lessing, F., and Zemceyny, S., Porphyrartige Struktur und Eutektik: Russ. k. mineral. Gesell. Verh., 2d ser., Band 44, pp. 244-256, 1906 
solutions, ${ }^{45}$ and (4) by replacement. However, it is desirable to recognize that the texture is not in itself a valid criterion of eutectic crystallization. The writer believes that the evidence is strong that the texture of the albite granite near Sparta results, at least in very large part, from replacement.

There are all gradations' between well-developed micrographic textures and irregular quartz intergrowths with feldspar, such as are seen in Plate $22 \mathrm{D}$, with less and less regular development of the components, eventually passing to isolated quartz areas in feldspars that might, except for the associated phenomena, pass for mere inclusions.

The vermiform, lobate, and venous disposition of the quartz of the albite granite is characteristic, and all gradations from thin tongues of quartz in albite to stringers and wisps of albite in a "sea" of quartz (pl. $22, B, C ; 23, A)$ are to be seen. These transitions are more and more striking the more albitic the rock. The fact that the lobes of quartz are dominantly oriented with their convexity toward the feldspar is believed to be significant of replacement. (See pls. 19, A; 22, D; $23, A$.) Very similar quartz grains, apparently working their way in along boundaries between plagioclase crystals and corroding associated microperthite, have been interpreted as suggestive of replacement by Wells and Wooldridge. ${ }^{46}$

Lacroix ${ }^{47}$ interpreted denticulate contacts of anorthite against the mafic minerals in the contact of the lherzolite of the Pyrenees as due to replacement. Similar structures have been so interpreted by Shaub, ${ }^{48}$ and the analogous orientation of lobate myrmekite toward microcline has been almost uniformly interpreted as evidence of replacement. ${ }^{49}$ The feature here discussed differs from myrmekite in that plagioclase rather than potash feldspar is the host mineral, and quartz alone rather than a quartz-albite intergrowth is the replacing mineral, but the forms are strictly analogous. Such textures have been interpreted as due to replacement by Callaway ${ }^{50}$ and Groves. ${ }^{51}$ In mineragraphic work similar textures have been interpreted as evidence of replacement..$^{52}$

\footnotetext{
${ }^{4}$ Schwartz, G. M., Experiments bearing on bornite-chalcocite intergrowths: Econ. Geology, vol. 23, pp. 388, 395, 1928.

${ }^{46}$ Wells, A. K., and Wooldridge, S. W., The rock groups of Jersey, with special reference to intrusive phenomena at Ronez: Geologists Assoc. Proc., vol. 42, p. 203, 1931.

${ }^{47}$ Lacroix, A., Les phénomènes de contact de la lherzolite et de quelques ophites des Pyrénées: Services carte géol. France Bull., vol. 6, No. 42, p 27, 1895.

${ }^{48}$ Shaub, B. M., A unique feldspar deposit near DeKalb Junction, N. Y.: Econ. Geology, vol. 24, p. 88, fig. 13, 1929.

${ }^{49}$ Fouqué, F., and Michel-Lévy, A., Minéralogie micrographique: Mém. Carte géol. France, p. 193, 1879. Sederholm, J. J., op cit., p. 135. Becke, F., op. cit., p. 382. Tronquoy, R., op. cit., p. 219-220. Tilley, C. E., The granite gneisses of the Southern Eyre Peninsula: Geol. Soc. London, Quart. Jour., vol. 77, pp. 87-88, 1921

${ }^{50}$ Callaway, C., Can a diorite become an acidic gneiss?: Geol. Mag., dec. 4, vol. 2, pp. 220-233, 1895.

${ }^{61}$ Groves, A. W., The heavy minerals of the plutonic rocks of the Channel Islands; 2,Guernsey, Sark, and Alderney: Geol. Mag., vol. 64, pp. 462-464, 1927.

${ }^{62}$ Schwartz, G. M., Copper veins on Susie Island, Lake Superior: Econ. Geology, vol. 23, p. 768, fig. 5 (p. 766), 1928. Lindgren, Waldemar, and Creveling, J. C., The ores of Potosi, Bolivia: Econ. Geology, vol. 23, p. 250, fig. 11 (p. 248), 1928. Lindgren, Waldemar, Pseudo-eutectic textures: Econ. Geology, vol. 25, p. 2, figs. 2-4, and elsewhere, 1930.
}

In the descriptive section of this paper attention was called to the presence of considerable albite with the habit to which the name "chessboard" (Schachbrett) albite has been given. It is pertinent that this variety of albite is commonly interpreted as resulting from replacement. ${ }^{53}$ In some occurrences there is no evidence of its being secondary, ${ }^{54}$ but excess mineralizers are even there regarded as having led to its formation. The occurrence of this variety of albite, commonly regarded as typical of replacement, lends some additional support to the more direct evidences of a secondary albitization of these rocks, though in view of Tilley's conclusion its intrinsic value as evidence is slight.

The occurrence of veinlets of albite penetrating cracks through all the other minerals (see pl. 22, $B$ ) is further evidence of permeation of the rock by albitic solutions after its consolidation.

The correlation between quartz and albite content on the one hand and cataclastic phenomena on the other has been commented on as suggesting a connection between the two. If this connection came about because the brecciation furnished channels of access for albitic siliceous solutions, the occurrence of crystalloblastic texture locally in the albite granite is quite consistent with this mechanism, as such solutions would be favorable to recrystallization of the rock, ${ }^{55}$ and when brecciation ceased, or even where the rock was locally sheltered during brecciation, crystalloblastesis would be expected.

\section{MINERALOGIC EVIDENCE}

The remarkable poverty of the feldspar in calcic plagioclase (much of it being at least as sodic as $A b_{95} A_{5}$ and accompanied by little zoisite or other saussuritic product) must be regarded as casting suspicion upon any hypothesis of a purely igneous origin of the albite granite.

As it is well known that the method of computing the norm throws the maximum lime into anorthite it is noteworthy that even the norms of Nos. 3 and 4 (p. 70) carry sodic oligoclase feldspars. Thus even if all the epidote now found in the albite granite were derived from original anorthite, the primary feldspar must have been close to $A b_{90}$, on any reasonable assumptions of the distribution of lime in the amphiboles. A plagioclase melt of such composition would be in equilibrium with crystals of a composition near sodic

${ }_{53}$ Goldschmidt, V. M., Die Kontaktmetamorphose im Kristianiagebiete: Vidensk. Skrifter, I, Mat.-Naturv. Klasse, 1911, No. 1, pp. 301-302; Übersicht der Eruptivgesteine im kaledonischen Gebirge zwischen Stavanger und Trondhjem: Idem, 1916, No. 2, pp. 68, 71, 78, 86. Becke, Friederich, Zur Physiographie der Gemengteile der Krystallinen Schiefer: K. k. Akad. Wiss., Mat.-Naturwiss. Klasse, Denkschr., Band 75, pp. 124-125, 1913. Grubenmann, U., and Niggli, P., Die Gesteinsmetamorphose, I, pp. 435-436, Berlin, 1924. Andersen, Olaf, The genesis of some types of feldspar from granite pegmatites: Norsk geol. Tidsskrift, Bind 10, H. 1-2, p. 151, 1928 .

${ }_{54}$ Tilley, C. E., The petrology of the granitic mass of Cape Willoughby, Kangaroo Island, pt. 1: Roy. Soc. South Australia Trans. and Proc., vol. 43, pp. 328-329, 1919 ${ }_{55}$ Sederholm, J. J., On migmatites and associated pre-Cambrian rocks of southwest Finland: Comm. géol. Finlande Bull., vol. 12, No. 77, pp. 124-125, 1926. Tyrrell, G. W., The principles of petrology, pp. 252-256, New York, 1927. 
andesine ${ }^{56}$ and as such could be derived as a rest magma from consolidating diorite. Such a derivation would not account for the comparative poverty in potash, however, and there is evidence that the selective enrichment in sodic feldspar with respect to potassic feldspar is dependent upon hydrothermal influences.

As long ago as 1875 Credner ${ }^{57}$ called attention to the fact that nearly pure albite is a good sign of hydrothermal action, and this has been recognized by many others since then. Schaller ${ }^{58}$ has stated that it is likely that no feldspar more sodic than $\mathrm{Ab}_{95} \mathrm{An}_{5}$ is ever pyrogenic. Whether or not this generalization will hold, there can be no question that most feldspars so sodic are of nonpyrogenic origin, and consequently their occurrence here is suggestive, if no more, of a replacement origin.

The blotchy development of hastingsite in parts of the common hornblende of the albite granite also indicates attack by sodic solutions upon the common green hornblende. The identity of the common hornblende with that of the quartz diorite indicates the close relations of the two rocks, and its blotching by hastingsite strongly suggests postmagmatic attack. This feature is paralleled by the formation of a "glaucophanelike" amphibole from common hornblende by circulating "late magmatic" solutions in a rock described by Colony. ${ }^{59}$

Other mineralogic evidence suggesting late magmatic or postmagmatic attack on the diorite to produce the albite granite consists in the widespread development of epidote and chlorite that is characteristic of the albite granite, in place of the usual pyrogenic mafic minerals, and especially the marked way in which the completeness of this substitution parallels the development of quartz and albite in the rock. Partly silicified and albitized rocks of this series ordinarily retain considerable common hornblende which, as the quantity of quartz increases, is altered to epidote and in part to small amounts of hastingsite.

The blue quartz of the albite granite, which owes its color to minute needles of rutile (?), is remarkably different from the colorless quartz of the quartz diorite. Many rocks of the transition series contain both kinds of quartz, which are readily distinguishable in hand specimens. The similarity in color of this quartz to that of many quartz nests in hydrothermally altered schist is striking. Although no importance could be reasonably ascribed to this similarity in itself, yet when it is considered in connection with the venous habit of much of the quartz and with the other evidences of hydrothermal replacement proc-

\footnotetext{
${ }^{56}$ Bowen, N. L., The evolution of the igneous rocks, p. 34, Princeton, 1928.

${ }^{57}$ Credner, Herman, Die granitischen Gänge des sächsischen Granulit-Gebirges: Deutsch. geol. Gesell. Zeitschr., vol. 27, p. 179, 1875.

${ }^{68}$ Schaller, W. T., The genesis of lithium pegmatites: Am. Jour. Sci., 5th ser., vol. 10, p. 279, 1925.

${ }_{59}$ Colony, R. J., The final consolidation phenomena in the crystallization of igneous rock: Jour. Geology, vol. 31, p. 173, 1923.
}

esses, it appears significant. It is noteworthy that rutile, especially in needle form, is commonly regarded as of hydrothermal origin ${ }^{60}$ and that it is the common titanium mineral in many rocks rich in albite and quartz as was pointed out by Geijer ${ }^{61}$ and Sundius. ${ }^{62}$

\section{SUMMARY OF MICROSCOPIC EVIDENCE}

The microscopic features strengthen the suggestion furnished by the field and chemical relations that the albite granite is a product of silicification and albitization of the quartz diorite in place. Features suggesting a replacement origin of the albite granite may be summarized as follows:

Textural features:

1. Cataclastic and crystalloblastic features are correlative with quartz and albite content.

2. The feldspars of the albite rock are partial pseudomorphs of those of the quartz diorite.

3. The forms of some feldspars suggest corrosion of andesine and its replacement by albite.

4. Myrmekite, limited to the albite granite, shows the existence of postmagmatic albitic solutions.

5. Veins of albite cutting earlier minerals are also evidence of postmagmatic albitic solutions.

6. The lobate penetrative forms of the quartz of the albite granite suggest replacement.

7. The micrographic texture of much of the albite granite is not inconsistent with a replacement origin.

Mineralogic features:

1. The remarkable poverty of the anorthite molecule in the albite granite renders a pyrogenic origin improbable.

2. Chessboard albite suggests a hydrothermal origin.

3. The blotchy development of hastingsite in parts of the hornblende of the albite granite suggests a later permeation of the rock by soda-rich solutions.

4. The widespread occurrence of epidote rather than other mafic minerals in the albite granite suggests hydrothermal processes.

5. The notably blue color of the quartz of the albite granite is suggestive of hydrothermal origin.

No one of the features just enumerated can be considered conclusive in itself of the correctness of the hypothesis advanced. Nevertheless, their cumulative force is great, and when taken in conjunction with the field relations and chemistry of the rocks they have led to the formulation of the replacement hypothesis.

\section{EVIDENCE OF THE VARIATION DIAGRAM}

On the variation diagram of Figure 2 are plotted the chemical compositions of the analyzed rocks. For comparison, a "normal" differentiation series, Bowen's weighted diagram of the Katmai voleanic rocks, and a soda granite series, Goldschmidt's "OpdaliteTrondhjemite Stamm," are plotted on the same diagram.

Bo Mügge, $\mathrm{O}$, in Rosenbusch, H., Mikroskopische Physiographie der petrographische wichtigen Mineralien, Band 1, Zweite Hälfte, 5th ed., pp. 94-95, 1927. Winchell, A. N., Elements of optical mineralogy; pt. 2, p. 53, New York, 1927. Gillson, J. L., and Kania, J. E. A., The genesis of the emery deposits near Peekskill, N. Y.: Econ. Geology, vol. 25, p. 515, 1930.

${ }_{61}$ Geijer, Per, Masugnsbyfältens geologi: Sveriges geol. Undersökning Årsbok, vol. 22, ser. C, No. 351, p. 37, 1928.

62 Sundius, N., On the differentiation of the alkalies in aplites and aplitic granites: Sveriges geol. Undersökning Årsbok, vol. 19, ser. C, No. 336, 1925. 
Some check upon the replacement hypothesis is furnished by this variation diagram. If the hypothesis is correct, there should be a tendency for the albitic rocks to show compositions intermediate between that of the quartz diorite and that of some pegmatitic "rest magma," and the plotted oxides of the several rocks should approach lines representing mixtures of such pegmatitic liquid and the original quartz diorite. This tendency should be only approximate, of course, because there is likelihood of selective replacement of some minerals with consequent variation from a
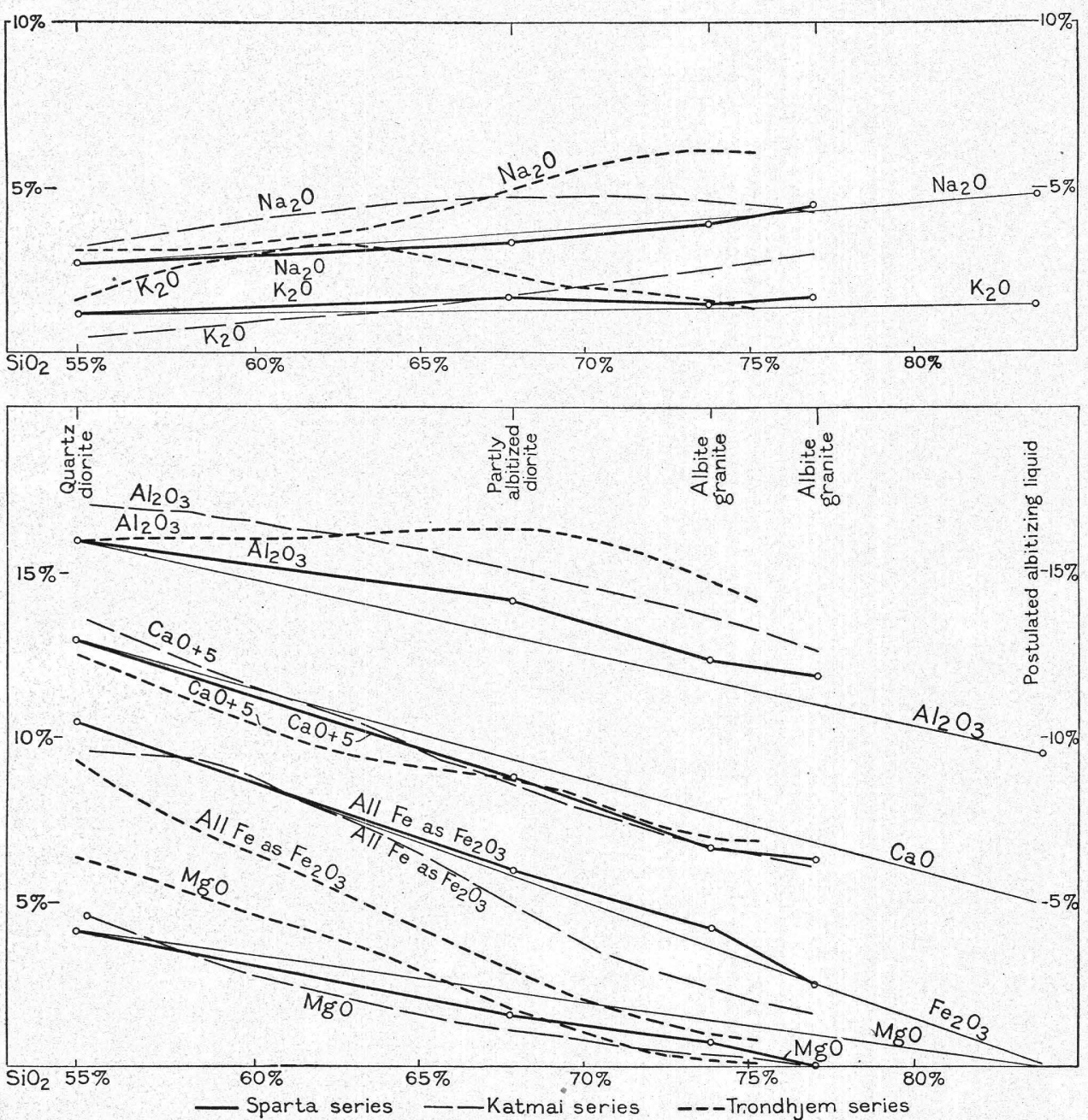

FIGURE 2.-Variation diagram showing chemical composition of quartz diorite and albite granite, with two intermediate rocks, contrasted with the weighted variation diagram of the Katmai rocks after Bowen (Evolution of the igneous rocks, p. 119, fig. 36, Princeton, 1928) and a variation diagram constructed from the analyses of the opdalite-trondhjemite series given by Goldschmidt (Übersicht der Eruptivgesteine im kaledonischen Gebirge zwischen Stavanger und Trondhjem: Vidensk. Skrifter, I, Mat.-Naturv. Klasse, 1916, No. 2, table opp. p. 140) lines connecting the values of the other oxides in the quartz diorite with values of the same oxides in the most siliceous albite granite were projected to zero. The line falling farthest to the right is that of $\mathrm{Fe}_{2} \mathrm{O}_{3}$, which falls to zero at 84 per cent $\mathrm{SiO}_{2}$. If the intermediate rocks were the result of simple mixing of the two end members, the composition of the siliceous member would be fixed by the oxide falling to zero first rather than last, but in view of the possibilities of selective replacement, the curve for iron oxides is believed to be more representative than that for magnesia. It is clear from the diagram that $\mathrm{K}_{2} \mathrm{O}$ is about constant, with a slight tendency to increase. It is therefore arbitrarily assumed that the pegmatitic juice mixing with the quartz diorite contained 84 per cent of $\mathrm{SiO}_{2}$ and 1.50 per cent of $\mathrm{K}_{2} \mathrm{O}$, the rest being the soda and alumina necessary for albite and orthoclase. This is computed to the following composition:

\section{Composition of assumed reacting liquid}

$\mathrm{SiO}_{2} \ldots \ldots$

$\mathrm{Al}_{2} \mathrm{O}_{3} \ldots \ldots \ldots \ldots \ldots$

$\mathrm{Na}_{2} \mathrm{O}$

$\mathrm{K}_{2} \mathrm{O}_{\ldots} \ldots \ldots \ldots \ldots$

99. 99

Mineral composition:

Quartz _..._...... 50.2

Albite.......... 40.9

Orthoclase $\ldots \ldots \ldots . . . . . .8$

Broken lines are drawn on the diagram connecting the points representing the oxides of the quartz diorite with the corresponding values for this hypothetical pegmatitic liquid.

It is obvious that the variation curves of all the oxides except $\mathrm{CaO}$ approximate much more closely to straight-line relation. Inasmuch as the "normal" course of differentiation itself tends toward a pegmatitic end product, the test of the hypothesis must be a closer approach of the intermediate rocks to a straightline relation between the quartz diorite and the postulated pegmatitic end stage than to the curves of the normal series, or to the curves of the opdalite-trondhjemite series, which are conceded to be governed almost wholly by magmatic processes.

As the microscopic evidence suggests addition of only soda, potassa, and silica in noteworthy quantities, the straight lines than to the lines of either the normal series or the opdalite-trondhjemite series. Even the $\mathrm{CaO}$ curve shows a slight tendency in the same direction.

The marked differences between the curves of the opdalite-trondhjemite series and those of the normal series render deductions as to origin from the variation diagram alone of doubtful value. The similarity of the curves of the Norwegian rocks and those of the Oregon rocks near the siliceous end would suggest on this basis that the Norwegian series contains similar 
replacement rocks. There is, indeed, some suggestion of local replacement phenomena in these more siliceous rocks ${ }^{63}$ leading to albite coating of oligoclase and the development of hornblende after augite and of chessboard albite, but the presence of oligoclase as the major plagioclase rather than albite, and of "antirapikiwi" rims of orthoclase about cores of oligoclase in some of the typical trondhjemites seems to preclude any quantitatively important replacement in them.

For these reasons it would be decidedly unwarranted to stress the testimony of the variation diagram, but it seems quite justifiable to point out the accordance between the actual curves and those to be expected under the simplest conditions of the replacement hypothesis. As corroborative evidence the variation diagram may be given considerably.more weight than it could claim intrinsically.

\section{SOURCE OF THE ALBITIZING SOLUTIONS}

If the conclusion that the albite granite owes its present composition to postmagmatic silicification and albitization is sound, one is immediately led to consider the possible sources of such solutions. The albitic and siliceous solutions may be thought of as originating (1) from near-by portions of the solid diorite, (2) from the intruded greenstones, (3) as restmagma solutions of local source, (4) as hydrothermal solutions of deep-seated origin. These possible sources are considered below.

\section{SOLUTIONS DERIVED FROM THE SOIID DIORITE BY METAMORPHISM}

Albitization in spilitic rocks has been attributed by Sundius ${ }^{64}$ to an exchange of soda for lime in one part of a rock body for a reciprocal replacement in an adjacent part, the composition of the mass as a whole remaining essentially unchanged during the metamorphism. The hypothesis was developed to explain the marked local variations in the quantities of albite and epidote in some of the Kiruna greenstones. There can be little doubt that such a process is locally effective. In the Sparta rocks, however, it can not be admitted as important, except, perhaps, in respect to the albite granites in the southern part of the Baker quadrangle, where they occur in saussurite gabbro. There is no sign that the near-by diorites have reacted with the albite granites, leading to a concentration of lime minerals in the diorites and of soda in the albite granites. The albite granites themselves are decidedly poor in dark minerals, so that the calcic reciprocal of the albitic rocks must, under this hypothesis, be sought in the adjacent diorites and gabbros. These rocks, however, are only moderately saussuritized: the small amounts of epidote and zoisite they contain can well have been

${ }^{63}$ Goldschmidt, V. M., op. cit. (1916), pp. $68,71,78,86$.

64 Sundius, Nils, Zur Frage Albitisierung: Geol. Fören. Forh., vol. 38, pp. 446 et seq., 1916. supplied locally and are quantitatively altogether disproportionate to the large masses of albite granite in the area, except, as just stated, in the southern part of the Baker quadrangle.

The same argument applies against an assumption that the sodic and siliceous solutions were derived by leaching from the adjacent diorites and gabbros during metamorphism. The feldspars of the diorites are so slightly altered that it is extremely unlikely that they could have supplied sufficient silica and soda to bring about the observed alterations of the albitic rocks, even were all the soda and silica that had been set free during saussuritization to be carried away. However, the well-known tendency in such changes is to fix the soda as albite, and this has certainly occurred in the saussurite of these rocks. The albite granites in the saussurite gabbro, in the southern part of the Baker quadrangle must again be excepted from those near Sparta.

\section{SOLUTIONS DERIVED FROM THE INTRUDED GREENSTONES}

The localization of the larger of the albite granite masses in the belt of outcrop of the Permian greenstones that are dominantly keratophyres and spilites suggests that a genetic relation may exist between them. This possibility is strengthened by the common association of soda granites and spilitic greenstones elsewhere, notably in the Caledonian mountains of Norway ${ }^{65}$ and in the British Isles, ${ }^{66}$ which has led Dewey and Flett to consider the soda granites a part of their "spilitic suite."

A review of the literature pertaining to other soda granites, as summarized in a later part of this paper, seems to show, however, that they are not limited to spilitic associations (as indeed is demonstrated by the occurrences in gabbro many miles from the nearest spilitic rocks in this same region), nor are they characteristically the products of magmas with notably high primary soda content.

If it is considered that the albitization of the quartz diorite is due to endomorphism consequent upon its intrusion into the older albitic greenstones, one would expect a rather close limitation of the alteration to the vicinity of the contacts. This is not found, however; some of the albite granite bodies are separated from the greenstones by considerable belts of unalbitized diorites. The large size of some bodies of albite granite is also unfavorable to such a transfer of soda and silica from the intruded into the intrusive bodies, for the few examples noted of such effeets of host rock upon intrusive are generally characterized by comparatively narrow zones of alteration.

65 Goldschmidt, V. M., Übersicht der Eruptivgesteine im kaledonischen Gebirge zwischen Stavanger und Trondhjem: Vidensk. Skrifter, I, Mat.-Naturv. Klasse, Bind 1, No. 2, 1916.

${ }_{66}$ Dewey, Henry, and Flett, J. S., On some British pillow lavas and the rocks associated with them: Geol. Mag., dec. 5, vol. 8, pp. 202-209, 1911. 
The fact that the intrusive rocks are younger than the greenstones obviously disposes of any possibility that solutions derived by autolysis of the spilitic greenstones, according to the hypothesis of either Dewey and Flett ${ }^{67}$ or Eskola, ${ }^{68}$ could have brought about the albitization of the diorites.

This is not an appropriate place to discuss the question of the spilites, but it may be that their association with soda granites in some localities, which led Dewey and Flett to regard the two as comagmatic, may on the contrary, be due to the action of similar albitizing solutions upon both rocks.

At least some of the albite granites of the Caledonian Mountains of Lapland are separated in age by a period of mountain building from the earlier spilitic rocks (keratophyres) with which they are geographically associated. Beskow ${ }^{69}$ can see no other relation between them than that existing between different bodies as a result of the action of similar differentiation processes at different geologic periods. The relations in eastern Oregon are similar. The local albitequartz masses in gabbro many miles from the nearest spilitic volcanic rocks and separated from them by a full geologic period seem to point to the correctness of Beskow's view.

\section{LOCAL REST-MAGMA SOLUTIONS}

It is the universally recognized result of magmatic crystallization to concentrate in a low-freezing residual magma larger proportions of the original alkalies and siliea than are to be found in the magma' as a whole. The selective enrichment of soda with respect to potassa is considered in a later section of this paper. Unquestionably this is the common origin of the sodic and siliceous mesostasis of many quartz diabases. Many of these diabases carry groundmasses whose composition approximates that of albite granites. Local conditions may well effect slight differences in the concentrations of such residual magmas or solutions, thus bringing about the production of some albite and quartz as the final residues in parts of a crystallizing rock. Doubtless it is this process which commonly leads to the formation of myrmekite and other synantetic products. The quantitative factor in the alterations of the Sparta rocks is believed to eliminate such a local process as the direct cause of their differences.

\section{HYDROTHERMAL SOLUTIONS OF DEEP-SEATED ORIGIN}

If, however, it is recognized that there is a common tendency toward the formation of such solutions rich in soda and silica, as exemplified in the micropegma-

\footnotetext{
67 Idem, pp. 204-205.

${ }^{68}$ Eskola, P., On the petrology of eastern Fennoskandia; I, The mineral development of basic rocks in the Karelian formations: Fennia, vol. 45, No. 19, pp. 89-91, 1925.

${ }^{69}$ Beskow, Gunnar, Södra Storfjället im südlichen Lappland, eine petrographische und geologische Studie im zentralen Teil des skandinavischen Hochgebirges: Sveriges geol. Undersökning Årsbok 21, No, 5, ser. C, No. 350, p. 298, 1927.
}

titic groundmasses of many quartz diabases, in the aplites associated with many diorites and granodio rites, and in the pegmatites of nearly all siliceous rocks, it becomes decidedly significant that the albite granite is apparently confined to the more brecciated parts of the dioritic intrusive bodies, that it is veined by quartz and albite, and that its amphiboles are blotched with sodic alteration products. These features are all compatible with a theory that would derive the albite granite from gabbro and diorite of the types of the adjacent rocks through the replacement of much of their mass by quartz and albite deposited from hydrothermal solutions circulating through breccia zones. If the course of crystallization of a magma leads to the production of such a sodic and siliceous rest magma, it is entirely possible that such magmatic residues might be expressed from the main igneous body and penetrate the earlier solidified apophyses along breccia zones, bringing about therein a considerable albitization and silicification. The solutions were, on this hypothesis, presumably derived from deeper levels in the igneous mass and were forced through the earlier solidified diorite by orogenic pressure.

\section{SELECTIVE ENRICHMENT OF SODA IN HYDRO- THERMAL SOLUTIONS}

According to the theory, of crystallization differentiation there should be, at least in "dry" magmas, no selective enrichment of soda with respect to potash in the later stages of magmatic crystallization. ${ }^{70}$ However, Goldschmidt, ${ }^{71}$ as well as Bowen, has shown that a high content of water in a magma may, through bringing about an early separation of biotite, lead to the suppression of potash feldspar in the low-temperature derivatives. The theory has likewise been exploited by Vogt. ${ }^{72}$ Biotite, though unquestionably a truly magmatic mineral in most occurrences, is by no means formed only under magmatic conditions but extends into the hydrothermal stage. In so far as it is hydrothermal, it would, like sericite, which is always hydrothermal, tend to impoverish the residual magmatic extracts in potash.

Goldschmidt's theory has been elaborated in considerable detail by Beskow, ${ }^{73}$ who has strongly urged its adequacy in producing soda enrichment in the later stages of magmatic development. However, he believes ${ }^{74}$ that the albite-epidote rocks of the "helsinkite facies" owe their special enrichment in albite to the instability of calcic plagioclase at comparatively low temperatures. In hydrous environments the unmixing of the plagioclase, which under normal conditions

70 Bowen, N. L., op. cit., p. 132.

${ }^{71}$ Goldschmidt, V. M., Stammestypen der Eruptivgesteine: Vidensk. Skrifter, I, Mat.-Naturv. Klasse, 1922, No. 10, pp. 6-7.

${ }^{72}$ Vogt, Thorolf, Sulitelmafeltets geologi og petrografi: Norges geo]. Undersökelse, No. 121 , p. 496,1927

${ }^{73}$ Beskow, Gunnar, op. cit., pp. 256-264. Beskow and Goldschmidt do not regard the formation of biotite as extending into the hydrothermal stage. In so far as it does, it cooperates with sericitization in depleting the solutions in potassa.

74 Idem, pp. 195-214. 
is only potential, proceeds readily with the production of epidote (or in special cases, amphibole) and the freeing of albite. Mild hydrothermal alteration thus results in saussuritization, but higher water concentrations may lead to the formation of large bodies of low-temperature hydrous magmas parental to the helsinkites. Beskow does not apply this mechanism to the production of hydrothermal solutions per se, but to the writer it seems an entirely feasible system.

Vogt ${ }^{75}$ has also regarded the late magmatic and early postmagmatic reactions in a granite as leading to the fixation of potassa in muscovite, which frees soda and lime. By reaction with potash feldspar myrmekite is formed, and the additional potash set free is, at least locally, fixed in mica, so that the only alkali thrown into the residual solutions is soda. Silica is of course freed with the soda, thus producing at a late stage sodic and siliceous solutions set free from the solid granite. These solutions effect contact alteration of the adjacent country rocks, which, according to Vogt, show that they have received additions of soda, lime, and silica. This "leaching of alkalies" also accounts, in Vogt's opinion, for the common occurrence of normative corundum in mica granites.

Tilley ${ }^{76}$ has considered it likely that highly albitic, mineralizer-rich liquids may result from the selective crystallization of potash feldspar from a rest magma in which both potash and soda were originally present in approximately equal quantities.

Thus the late deposition of albite rather than potash feldspar from hydrothermal solutions may be due not to absence of potassa in the solution but to the stability ranges of the feldspars, albite being the stable one at low temperatures. According to Grubenmann and Niggli, ${ }^{77}$ where both alkalies have been enriched during contact metamorphism, it is common to find the potash enrichment older than the soda enrichment. The replacement of microcline by albite in the later stages of pegmatite formation is clear evidence of the same fact. $^{78}$

That solutions capable of causing albitization are not confined to pegmatites is amply demonstrated by the widespread occurrence of myrmekite, by albite impregnation in contact metamorphism ${ }^{79}$ especially in adi-

\footnotetext{
${ }^{75}$ Vogt, Thorolf, op. cit., pp. 524-525.

76 Tilley, C. E., op. cit., pp. 335-337.

77 Grubenmann, U., and Niggli, Paul, Die Gesteinsmetamorphose, I, p. 293, Berlin, 1924.

${ }^{78}$ Brögger, W. C., Die Mineralien der Syenitpegmatitgänge der Südnorvegischen Augit- und Nephelinsyenite: Zeitschr. Kryst. Min., vol. 60, p. 167, 1890. Schaller, W. T., op. cit., p. 279. Hess, F. L., The natural history of the pegmatites: Eng. and Min. Jour., vol. 120, pp. 289-298, 1925 . Landes, K. K., The paragenesis of the granite pegmatites of central Maine: Am. Mineralogist, vol. 10, pp. 371-374, 1925; Sequence of mineralization in the Keystone, S. Dak., pegmatites: Am. Mineralogist, vol. 13, p. 552, 1928. Anderson, Olaf, The genesis of some types of feldspar from granite pegmatites: Norsk geol.Tidskr., Bind 10, pp. 204-205, 1928.

${ }^{79}$ La Croix, A., Les phénomènes de contact de la lherzolite et de quelques ophites des Pyrénées: Service carte géol. France Bull., vol. 6, No. 42, pp. 84-86, 93, 99-100, 107, 125-133, 1895. Goldschmidt, V. M., Die Kontaktmetamorphose im Kristianiagebiete: Vidensk. Skrifter, I, Mat.-Naturv. Klasse, 1911, pp. 36, 57-58, 300, 312-313;
} idem, 1916, No. 2, p. 93. noles, ${ }^{80}$ and by the common occurrence of postmagmatic albitization both in granitic rocks and in basic or intermediate intrusive and extrusive rocks. ${ }^{81}$ Some of these alterations are on a scale comparable to that shown in the Sparta rocks.

Eskola ${ }^{82}$ states that the normal course of crystallization should produce a segregation of alkali silicates and water in the magmatic residue at the lower temperatures and, without discussing the fate of the potash concentrate, regards the common occurrence of albitization as a result of this alkaline enrichment of the rest magma. Although Eskola is quite logical in regarding delessite and serpentine, which usually accompany this albitization, as low-temperature members of the mafic reaction series, most writers regard these minerals as diagnostic of hydrothermal rather than magmatic processes. At any rate, as Eskola has pointed out, there is no reason why such residual magma extracts should not separate from the main magma body and act upon "consolidated portions of the same rock mass or even adjacent rocks." Such extracts, according to the theory here developed, were responsible for the alteration of the gabbro and quartz diorite to albite granite.

\section{ALBITIZATION IN OTHER GRANITIC ROCKS}

Although large-scale albitization such as is postulated by the hypothesis here advanced for the origin of the Sparta rocks has not, so far as known to the writer, been previously suggested, the occurrence of similar phenomena on a smaller scale is widespread, and the process of late albitization has been recognized in several places in recent years. Holmquist ${ }^{83}$ has described corroded basic feldspars surrounded by albite in the Filipstad granite of Sweden. Phillips ${ }^{84}$ has described albitization in a Shetland dike. De Lapparent ${ }^{85}$ has described albitization (regarded by him as magmatic) in some microgranites. Tronquoy, ${ }^{86}$

${ }_{80}$ Teall, J. J. H., British petrography, pp. 219-221, London, 1888. Hutchings, W. M., An interesting contact rock, with notes on contact metamorphism: Geol. Mag., dec. 4, vol. 2, p. 130, 1895. Bowen, N. L., Diabase and granophyre of the Gowganda Lake district, Ontario: Jour. Geology, vol 18, p. 664, 1910. Milch, L., Über Adinolen und Adinoleschiefer des Harzes: Deutsch. geol. Gesell. Zeitschr., vol. 69, pp. 349486, 1917. Gillson, J. L., op. cit. (1927), p. 8.

${ }^{81}$ Bailey, E. B., and Grabham, G. W., Albitization of basic plagioclase feldspars: Geol. Mag., dec. 5, vol. 6, pp. 250-256, 1909. Dewey, Henry, and Flett, J. S., On some British pillow lavas and the rocks associated with them: Geol. Mag., dec. 5, vol. 8, pp. 202-209, 241-247, 1911. Cox, A. H., The geology of the district between Abereiddy and Abercastle: Geol. Soc. London Quart. Jour., vol. 71, p. 330, 1915 Spencer, A. C., The Juneau gold belt, Alaska: U. S. Geol. Survey Bull. 287, pp. 101, 111, 1906. Knopf, Adolph, Geology of the Berners Bay region, Alaska: U. S. Geol. Survey Bull. 446, pp. 32-34, 1911; The Eagle River region, southeastern Alaska: U.S. Geol. Survey Bull. 502, pp. 37-41, 1912.

82 Eskola, Pentti, On the petrology of eastern Fennoskandia, I, The mineral development of basic rocks in the Karelian formations: Fennia, vol. 45, No. 19, pp. 89-92, 1925.

${ }^{83}$ Holmquist, P. J., Studien über die Granite von Schweden: Geol. Inst. Upsala Bull., vol. 7, p. 171, 1906.

${ }^{84}$ Phillips, F. C., Note on a riebeckite-bearing rock from the Shetlands: Geol. Mag., vol. 63, pp. 72-77, 1926.

85 De Lapparent, J., Étude comparative de quelques porphyroïdes françaises: Soc. française minéralogie Bull., vol. 32, pp. 243-263, 1909.

${ }_{80}$ Tronquoy, R., Contribution à l'étude des gîtes d'étain: Soc. française minéralogie Bull., vol. 35, p. 334, 1912; Origine de la myrmékite: Idem, p. 222. 
Colony, ${ }^{87}$ and Sugi ${ }^{88}$ have also recognized late magmatic albitization. Albite replacement of microcline is regarded by Suter ${ }^{89}$ and Niggli ${ }^{90}$ as a consequence of the low temperature-stability range of albite rather than of any material difference in the concentration of soda with respect to potassa. Pflugshaupt ${ }^{91}$ has thought that the process is advanced by pressure.

Horwood and Wade ${ }^{92}$ have referred the albite feldspar of the Orange Grove granite of the Transvaal to secondary alterations of original oligoclase.

The masterly research of Thomas ${ }^{93}$ on the igneous centers of Ardnamurchan contains numerous records of albitization of the intrusive rocks. Among them is the alteration of the gabbro and quartz gabbro west of Faskadale Bay, ${ }^{94}$ where the basic plagioclases are all more or less albitized and the augite is altered to hornblende. In places the rocks contain a groundmass of quartz and alkaline feldspar, rich in apatite. The alteration may be due to an associated intrusion of granophyre. In another locality a hypersthene gabbro shows marginal facies much acidified by a partial magma, presumably derived from the hypersthene gabbro itself, which permeates the border zone irregularly. Locally it makes the whole rock a granophyre; elsewhere it merely forms granophyre patches in the gabbro. ${ }^{95}$ The gabbro feldspars are partly resorbed and altered to oligoclase-albite. Apatite is plentiful, and tourmaline occurs locally, testifying to the presence of mineralizers. "Acid" veins of similar composition cut the outer margin of the gabbro. They carry irregular quartz of granophyric habit but not obvious micrographic texture. The illustrations ${ }^{96}$ resemble textures seen in the Sparta rocks.

At another locality eucrite is altered by an "acid" partial magma, with the development of biotite. An "acid" mesostasis was observed in nearly all specimens and in many constitutes a considerable part of the rock. ${ }^{97}$ It then forms turbid and in places graphic perthitic feldspar-quartz intergrowths, with abundant apatite, which attack, corrode, and replace the basic feldspars with albite. Albitic fringes surround basic

${ }^{87}$ Colony, R. J., Final consolidation phenomena in the crystallization of igneous rocks: Jour. Geology, vol. 31, p. 173, 1923.

${ }^{88}$ Sugi, K., On the granitic rocks of the Tsukuba district and their associated injection rocks: Japanese Jour. Geology and Geography, vol. 8, p. 60 and elsewhere, 1930.

${ }^{89}$ Suter, Hans, Zur Petrographie des Grundgebirges von Laufenburg und Umgebung: Schweiz. min. pet. Mitt., Band 4, pp. 314-317, 1924.

90 Niggli, Paul, Versuch einer natürlichen Klassifikation der im weiteren Sinne magmatischen Erzlagerstätten: Abh. prakt. Geologie und Bergwirtschaftlehre, Band 1, pp. 11-13, 1925.

${ }_{91}$ Pflugshaupt, Paul, Beiträge zur Petrographie des östlichen Aarmassivs: Schweiz. min. pet. Mitt., Band 7, p. 348, 1927.

92 Horwood, C. B., and Wade, A., The old granites of Africa: Geol. Mag., dec. 5, vol. 6, pp. 549-554, 1909.

${ }^{83}$ Richey, J. E., and Thomas, H. H., The geology of Ardnamurchan, Northwest Mull and Coll: Scotland Geol. Survey Mem., 1930.

${ }_{94}$ Idem, p. 147.

${ }_{95}$ Idem, p. 227.

${ }^{96}$ Idem, fig. 30a, p. 229.

${ }_{97}$ Idem, p. 325. feldspars. Hornblende and biotite have developed at the expense of augite. The albitic fluid seems to follow shatter cracks in the minerals. Bending and breaking of twin lamellae of the calcic plagioclase is always followed by albitization. Both phenomena are attributed by Thomas to the pressure exerted by the crystallization of a volatile-charged acid magma. Gradations occur from little or no acid material in the gabbro to little gabbro in a mass of acid material.

Except for the Shetland, Ardnamurchan, and Transvaal rocks, none of the rocks described by these workers are highly albitic; nevertheless, the widespread occurrence of very sodic feldspars associated with replacement phenomena in other rocks indicates how commonly, though on so much smaller a scale, the processes appealed to in explaining the origin of the Sparta rocks have been operative.

\section{OTHER ALBITE GRANITES}

Rocks having the composition of typical albite granites have been described from occurrences in many parts of the world and in association with many kinds of other rocks. It is certain that, whatever may be true of some of these rocks, there is no suggestion that a primary sodic magma is necessary for their origin. Such a magma is, of course, unnecessary for other soda-rich siliceous rocks, many of which have originated from normal subalkaline rocks. For instance, the alkaline granites of eastern Massachusetts ${ }^{98}$ and the soda-rich granites of the Riesengebirge ${ }^{99}$ are both supposedly derived from subalkaline magmas. Similarly, the trondhjemites of Norway have been regarded as derivatives of normal gabbroid magma. ${ }^{1}$

\section{FIELD ASSOCIATIONS}

Albite granites and albitites are known in association with dioritic and more basic intrusive rocks in the Sierra Nevada, ${ }^{2}$ Czechoslovakia, ${ }^{3}$ Victoria,${ }^{4}$ Wales, ${ }^{5}$ British Columbia, ${ }^{6}$ and Nevada. ${ }^{7}$ They occur in

${ }_{98}$ Loughlin, G. F., and Hechinger, L. A., An unconformity in the Narragansett Basin of Rhode Island and Massachusetts: Am. Jour. Sci., 4th ser., vol. 38, p. 55, 1914.

${ }^{9}$ Milch, L., Beiträge zur Kenntniss der granitischen Gesteine des Riesengebirges: Neues Jahrb:, Beilage-Band 15, pp. 170-172, 1902. See also paper on adinoles previously cited, where albitic differentiates are shown to be normal products of subalkaline magmas.

1 Goldschmidt, V. M., Stammestypen der Eruptivgesteine: Vidensk. Skrifter, I, Mat.-Naturv. Klasse, 1922, No. 10, pp. 6-7. Vogt, Thorolf, Sulitelmafeltets geologi og petrografi: Norges geol. Undersökelse, No. 121, p. 496, 1927.

2 Turner, H. W., The granitic rocks of the Sierra Nevada: Jour. Geology, vol. 7, pp. 155-156, 1899. Reid, J. A., The east country of the Mother Lode: Min. and Sci. Press, vol. 94, pp. 279-280, 1907.

${ }^{3}$ Hinterlechner, K., and Von John, C., Über Eruptivgesteine aus dem Eisengebirge in Böhmen: K.-k. geol. Reichsanstalt Jahrb., vol. 59, pp. 134-138, 1909.

${ }^{4}$ Howitt, A. W., The rocks of Noyang: Roy. Soc. Victoria Trans., vol. 20, pp. $40-48,1884$.

${ }^{5}$ Thomas, H. H., and Jones, O. T., On the pre-Cambrian rocks of Brawdy, Hayscastle, and Brimaston: Geol. Soc. London Quart. Jour., vol. 68, pp. 387-388, 1912.

${ }^{6}$ McCann, W. S., Bridge River Map area: Canada Geol. Survey Mem. 130, p. $67,1922$.

7 Ransome, F. L., Notes on some albitite dikes from Nevada: Washington Acad. Sci. Jour., vol. 1, pp. 114-118, 1911. 
association with subalkaline granite in the Riesengebirge, ${ }^{8}$ in Finland, ${ }^{9}$ in Sweden, ${ }^{10}$ in the Transvaal, ${ }^{11}$ in Georgia, ${ }^{12}$ and in South Australia. ${ }^{13}$

Rocks with the composition of albite granite occur with diabase in Ontario, ${ }^{14}$ Scotland, ${ }^{15}$ and Sweden..$^{16}$ They are associated with sodic felsites in Ireland, ${ }^{17}$ Wales, ${ }^{18}$ and Scotland ${ }^{19}$ and with borolanite in Scotland. ${ }^{20}$

Högbom describes granophyric albite granite as a border facies of ordinary granite against sodic leptites. He regards it as due to contamination. ${ }^{21}$

\section{MINERALOGICAL AND TEXTURAL FEATURES}

Despite the diversity of rock associations in which these rocks are found, they have many features in common. Among them is the very frequent occurrence of epidote either as the sole dark mineral or as the predominant one. The helsinkite of Finland, ${ }^{22}$ the soda granite porphyry of the Sierra Nevada, ${ }^{23}$ and the albite granites of Georgia, ${ }^{24}$ the Transvaal, ${ }^{25}$ Switzerland, ${ }^{26}$ Sweden, ${ }^{47}$ Czechoslovakia, ${ }^{28}$ Scotland, ${ }^{29}$ and the Shetlands ${ }^{30}$ all carry epidote as either the sole or dominant mafic constituent; chlorite, also a low-temperature hydrous mineral, is the chief mafic

${ }^{8}$ Milch, L., op. cit., pp. 170-172.

9 Eskola, Pentti, Petrology of the Orijarvi region: Comm. géol. Finlande Bull., vol. 8, No. 40, 1914. Mäkinen, Eero, Pre-Cambrian geology of central Österbotten in Finland: Comm. géol. Finlande Bull., vol. 9, No. 47, pp. 143, 146, 1916.

10 Geijer, Per, Masugnsbyfältens geologi: Sveriges geol. Undersökning Årsbok 22, No. 1, ser. C., No. 351 , pp. 36-38. 1928. Sundius, N., On the differentiation of the alkalies in aplites and aplitic granites: Sveriges geol. Undersökning Årsbok 19, No. 3, ser. C, No. 336, 1925.

11 Horwood, C. B., and Wade, A., op. cit., pp. 549-554.

12 Watson, T. L., Granites and genisses of Georgia: Georgia Geol. Survey Bull. 9A, pp. 76-77, 1902.

${ }_{13}$ Tilley, C. E., The petrology of the granitic mass of Cape Willoughby, Kangaroo Island, pt. 1: Roy. Soc. South Australia Trans. and Proc., vol. 43, pp. 328-338, 1919 Browne, W. R., The igneous rocks of Encounter Bay: Roy. Soc. South Australia Trans. and Proc., vol. 44, pp. 1-57, 1920

14 Bowen, N. L., Diabase and aplite of the Cobalt silver area: Canadian Min Inst. Jour., vol. 12, pp. 523-527, 1909. Collins, W. H., Gowganda mining division. Canada Geol. Survey Mem. 33, pp. 64-68, 1913.

${ }^{15}$ Falconer, J. D., The igneous geology of the Bathgate and Linlithgow Hills: Roy. Soc. Edinburgh Trans., vol. 45, pp. 147-148, 1908.

16 Holmquist, P. J., Om Rödöområdets rapakivi och gångbergarter: Sveriges geol. Undersökning, ser. C, No. 181, pp. 83-84, 1899.

${ }^{17}$ Hatch, F. H., On the occurrence of soda felsites (keratophyres) in County Wicklow, Ireland: Geol. Mag., dec. 3, vol. 6, pp. 70-73, 1889.

18 Thomas, H. H., and Jones, O. T., op. cit., pp. 380-381.

19 Flett, J. S, The geology of Knapdale, Jura, and North Kintyre: Scotland Geol. Survey Mem. 28, pp. 93-95, 1911.

${ }^{20}$ Clough, C. T., The geological structure of the northwest Highlands of Scotland: Great Britain Geol. Survey Mem. p. 32, 1907.

${ }^{21}$ Högbom, Ivar, Petrografiska studier Vid Nybergsfältet: Geol. Fören. Förh. vol. 42 , p. 174,1920 .

${ }^{22}$ Laitakari, A., Einige Albitepidotgesteine von Süd Finland: Comm. géol. Finlande Bull., vol. 9, No. 51, 1918. Mäkinen, Eero, op. cit., pp. 145-146.

${ }_{23}$ Butler, B. S., Pyrogenetic epidote: Am. Jour. Sci., 4th ser., vol. 28, pp. 27-32, 1909.

${ }^{24}$ Watson, T. L., op. cit., p. 77.

${ }^{25}$ Horwood, C. B., and Wade, A., op. cit., p. 549.

${ }^{26}$ Grubenmann, U., Beiträge zur Geologie des Unterengadines, Teil 2, Die Kristallinen Gesteine: Beiträge geol. Karte Schweiz, Neue Folge, Lief. 23, p. 194, 1909.

${ }^{27}$ Beskow, Gunnar, Södra Storfjället im südlichen Lappland, eine petrographische und geologische Studie im zentralen Teil des skandinavischen Hochgebirges: Sveriges geol. Undersökning Årsbok 21, No. 5, ser. C, No. 350, pp. 137$179,1927$.

${ }^{28}$ Hinterlechner K., and Von John, op. cit., p. 135.

${ }^{29}$ Flett, J. S., op. cit. (1911), p. 93.

${ }^{30}$ Phillips, F. C., op. cit., p. 74. mineral in the albite-quartz porphyrite ${ }^{31}$ of Victoria. Evidences of particular richness in water have been noted in many of the rocks; in fact, nearly every description of highly albitic and siliceous intrusive rocks that the writer has been able to find contains mention of a notably high content of water in the parent magma. This feature is also noted by Daly, ${ }^{32}$ although he emphasizes resurgent rather than juvenile water as the agent.

Evidences of replacement or features suggesting some replacement also seem to be especially common among these rocks. Brögger describes albite rims about microperthite crystals in a soda granite from Norway, ${ }^{33}$ and their occurrence is suggestive of replacement though not convincing. Sollas's description of granophyre veins in gabbro with nests or "miarolitic cavities" in the gabbro filled by quartz and feldspar crystals "of larger dimensions than the feeding dikelets" certainly suggests replacement. ${ }^{34}$ The granophyre, though albitic, carries principally potash feldspar.

According to Harker, ${ }^{35}$ the highly albitic Carrock Fell granophyre corrodes the gabbro in contact with it. Some of the features mentioned by Harker are suggestive of replacement, although it is probable that such phenomena are not on a very large scale. Phillips ${ }^{36}$ has regarded some but not all of the albite in his riebeckite-bearing Shetland dike as of replacement origin. Some of the quartz-feldspar relations in the very siliceous border facies of the Eskdale granite described by Dwerryhouse ${ }^{37}$ are highly suggestive of replacement. The feldspar involved is, however, oligoclase rather than albite. Most of the highly sodic microgranites described by De Lapparent ${ }^{38}$ show replacement phenomena, so interpreted by him, with, however, the belief that the replacements were magmatic and occurred prior to the consolidation of the rock. The evidence he advances to fix the time of the replacements does not seem to the present writer at all convincing, as it is based chiefly on the idea that fractured feldspars would not normally retain their angular shapes during replacement, and hence that broken albite feldspars are of prebrecciation origin.

${ }^{31}$ Howitt, A. W., op. cit., pp. $43,46$.

${ }^{32}$ Daly, R. A., Igneous rocks and their origin, pp. 243, 339-340, 437, New York, 1914.

${ }^{33}$ Brögger, W. C., Die Eruptivgesteine des Kristianiagebietes: I, Die GroruditTinguait Serie: Vidensk. Skrifter, I, Mat.-Naturv. Klasse, 1894, No. 4, pp. 127, 128. ${ }^{34}$ Sollas, W. J., On the volcanic district of Carlingford and Slieve Gullion, pt. 1, On the relation of the granite to the gabbro of Barnavave, Carlingford: Roy. Irish Acad. Trans., vol. 30, pp. 477-512, 1894.

${ }^{35}$ Harker, A., Carrock Fell-a study in the variation of igneous rock masses, pt. 2, The Carrock Fell granophyre: Geol. Soc. London Quart. Jour., vol. 51, pp. 135-137, 1895.

${ }^{36}$ Phillips, F. C., op. cit., p. 74.

${ }^{37}$ Dwerryhouse, A. R.. On some intrusive rocks in the neighborhood of Eskdale, Cumberland: Geol. Soc. London Quart. Jour., vol. 65, p. 63, pl. 3, fig. 2, p. 65, 1909.

${ }^{38}$ De Lapparent, J., op. cit., pp. 243, 244, 246, 248, 269. 
"Poikilitic" quartz in feldspars of the albite granite of the Riesengebirge may well be of replacement origin. ${ }^{39}$ Some of the quartz in the segregation veins in the quartz diabase described by Falconer ${ }^{40}$ is regarded by him as secondary. The albite of the Orange Grove granite is regarded by Horwood and Wade ${ }^{41}$ as having replaced oligoclase. Geijer has described albite granite selvages along potash granite contacts which he regards as perhaps due to albitization. ${ }^{42}$ Descriptions in the literature are commonly somewhat obscure, and other albite granites may possess replacement features. It is probable that some do not, however.

Other noteworthy features of albite granites and albitites include the common presence of quartz ${ }^{43}$ of a notably milky color, due perhaps, as in the Swedish examples cited on page 74 , to rutile inclusions, and the still more common occurrence of graphic or micrographic texture. The enumeration of all the occurrences of graphic textures in these rocks would include well over half of all to which the writer has found reference.

Another noteworthy feature of these albite-rich rocks is their common association with crushing phenomena. Cataclastic features have been mentioned by Horwood and Wade, ${ }^{44}$ Elsden, ${ }^{45}$ Grubenmann, ${ }^{46}$ Hinterlechner and Von John, ${ }^{47}$ and Thomas. ${ }^{48}$

${ }^{39}$ Milch, L., op. cit., pp. 177-178.

40 Falconer, J. D., op. cit., p. 149.

${ }^{41}$ Horwood, C. B., and Wade, A., op. cit., p. 550.

${ }^{42}$ Geijer, Per, Geology of the iron-ore fields at Masugnsbyn: Sveriges geol. Undersökning Årsbok 22, No. 1, ser. C, No. 351, pp. 37-38, 1928.

43 Jaquet, J. B., Geology of the Broken Hill lode and Barrier Ranges mining field: New South Wales Geol. Survey Mem., Geology No. 5, pp. 50-53, 1894. Milch, L.,

op. cit. (1899), p. 184 . Tilley, C. E., op. cit. (1919), p. 329.

${ }^{44}$ Horwood, C. B., and Wade, A., op. cit., p. 550 .

${ }^{45}$ Elsden, J. V., On the St. David's Rock series: Geol. Soc. London Quart. Jour vol. 64 , p. $275-277,1908$

${ }^{46}$ Grubenmann, U.,Beiträge zur Geologie des Unterengadines, Teil 2, Die Kristallinen Gesteine: Beitr. geol. Karte Schweiz, Neue Folge, Lief. 23, pp. 191-192, 1909

${ }^{47}$ Hinterlechner, K., and Von John, C., op. cit., pp. 134-138.

48 Thomas, H. H., op. cit., p. 325 and others.

\section{CONCLUSION}

It has been shown that many albite granites elsewhere are characterized by features found in the Sparta rocks. These include common association with crushing phenomena, widespread occurrence of graphic textures, of epidote and other low-temperature and hydrous mafic minerals, and of milky and rutilated quartz, and unusual amounts of replacement. Although there is a temptation to generalize from these features and conclude that albite granites in general originated through the replacement processes to which the writer has referred the origin of the Sparta rocks, it is probable that such a generalization would be unsound. The findings of the writer with respect to the Sparta rocks are in agreement with the thesis of Bowen ${ }^{49}$ that albite granites are of hydrothermal origin, but it does not appear that a survey of the world literature on such rocks is at all conclusive on the matter. It seems that albite granites may well originate in different ways. Indeed, as Knopf ${ }^{50}$ has pointed out, the occurrence of highly siliceous and soda-rich volcanic glasses is very suggestive that liquids of the composition of albite granite can be and are produced by magmatic differentiation. Though the present study seems to support Bowen's conclusion, the writer feels that it is too early to assert that the conclusion has universal validity.

\section{ACKNOWLEDGMENTS}

The painstaking criticism of the manuscript and helpful discussions of the problem by T. B. Nolan and C. S. Ross, of the United States Geological Survey, are gratefully acknowledged. Many of the photomicrographs were taken by $M$. N. Short, of the Geological Survey.

${ }^{49}$ Bowen, N. L., The evolution of the igneous rocks, p. 132, Princeton, 1928.

${ }^{50} \mathrm{Knopf,}$ Adolph, review of Bowen, N. L., Evolution of the igneous rocks: Am. Jour. Sci., 5th ser., vol. 17, p. 380, 1929. 